\title{
Deliberations on the impact of antibiotic contamination on dissemination of antibiotic resistance genes in aquatic environments
}

\author{
Björn Berglund
}

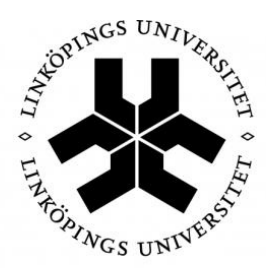

\section{Linköping University \\ FACULTY OF HEALTH SCIENCES}

Division of Medical Microbiology

Department of Clinical and Experimental Medicine

Faculty of Health Sciences

Linköping University

Linköping 2014 
(C) Björn Berglund, 2014

Printed by LiU-Tryck, Linköping 2014

ISBN: 978-91-7519-361-8

ISSN: 0345-0082 




\section{Abstract}

The great success of antibiotics in treating bacterial infectious diseases has been hampered by the increasing prevalence of antibiotic resistant bacteria. Not only does antibiotic resistance threaten to increase the difficulty in treating bacterial infectious diseases, but it could also make medical procedures such as routine surgery and organ transplantations very dangerous to perform. Traditionally, antibiotic resistance has been regarded as a strictly clinical problem and studies of the problem have mostly been restricted to a clinical milieu. Recently, non-clinical environments, and in particular aquatic environments, have been recognised as important factors in development and dissemination of antibiotic resistance. Elevated concentrations of antibiotics in an environment are likely to drive a selection pressure which favours resistant bacteria, and are also believed to promote horizontal gene transfer among the indigenous bacteria. Antibiotic resistance genes are often located on mobile genetic elements such as plasmids and integrons, which have the ability to disseminate among taxonomically unrelated species. The environmental bacteria can thus serve as both reservoirs for resistance and hot spots for the development of new antibiotic resistance determinants.

There is still a lack of data pertaining to how high antibiotic concentrations are necessary to drive a selection pressure in aquatic environments. The aim of this thesis is to determine the effect of high and low concentrations of antibiotics on environmental bacterial communities from different aquatic environments. In the studies performed, antibiotics were measured using liquid chromatography-mass spectrometry. Bacterial diversity and evenness were assessed using molecular fingerprints obtained with 16S rRNA gene-based denaturing gradient gel electrophoresis, and antibiotic resistance genes and class 1 integrons were quantified using real-time PCR.

Water and sediment samples were collected from different rivers and canals in Pakistan. The environments differed in anthropogenic exposure from undisturbed to heavily contaminated. A general trend could be observed of high concentrations of antibiotics correlating to elevated concentrations of antibiotic resistance genes and integrons. Extremely high concentrations of antibiotic resistance genes and integrons were found in the sediments downstream of an industrial drug formulation site, which likely correlated to the high load of antibiotics found in the water. Antibiotic and antibiotic resistance gene concentrations were also shown to increase downstream of Ravi river, which flows through Lahore, a city of more than 10 million inhabitants. Rivers not impacted by anthropogenic contamination were found to contain antibiotics and resistance gene concentrations of similar levels as in Europe and the U.S. Similar measurements were performed in the Swedish river Stångån. The concentrations of antibiotic resistance genes and class 1 
integrons were shown to increase in the river after it had passed, and received urban wastewater effluent from the city of Linköping.

A series of constructed wetlands were exposed to a mixture of different antibiotics at environmentally relevant concentrations over a few weeks. The antibiotic exposure did not observably affect the bacterial diversity or integron concentrations. Antibiotic resistance genes were found at low background concentrations, but the antibiotic exposure did not observably affect the concentrations. The constructed wetlands were also found to reduce most antibiotics at levels comparable to conventional wastewater treatment schemes, suggesting that constructed wetlands may be useful supplementary alternatives to conventional wastewater treatment.

To investigate the effect of antibiotics on an uncontaminated aquatic environment in a more controlled setting, microcosms were constructed from lake water and sediments and subsequently exposed to varying concentrations of antibiotics (ranging from wastewater-like concentrations to 1,000 times higher). The water and sediments were gathered from the lake Nydalasjön, near Umeå, which is not exposed to urban waste. While antibiotic resistance genes and class 1 integrons were found in the lake sediments, no increase in the concentrations of these genes could be observed due to the antibiotic additions.

In conclusion, although antibiotic resistance genes and integrons are part of the environmental gene pool, low concentrations of antibiotics do not seem to immediately impact their prevalence. However, aquatic environments exposed to anthropogenic waste do exhibit elevated levels of antibiotic resistance genes and integrons. Aquatic environments heavily polluted with antibiotics also clearly display correspondingly high concentrations of antibiotic resistance genes and integrons. These results clearly indicate the necessity to keep down pollution levels as well as the need to establish the range of antibiotic concentrations which do promote resistance. This must be done in order to enable risk assessments and to establish acceptable levels of antibiotic pollution. It should also be stressed that more research is required to elucidate what effect low levels of antibiotic exposure has on environmental bacterial communities. 


\section{Populärvetenskaplig sammanfattning}

Antibiotikaresistens är ett växande problem världen över som sannolikt kommer att kräva internationellt gemensamma samarbeten för att klara upp. Ett misslyckande att lösa problemet skulle bl.a. kunna leda till att vanliga infektionssjukdomar blir omöjliga att behandla och att rutinmässiga kirurgiska ingrepp blir problematiska att genomföra. Lösningen på antibiotikaresistensproblematiken har oftast sökts inom sjukvården, där effekterna av problemet syns mest markant. På senare tid har det dock uppmärksammats allt mer att antibiotikaresistensgener kan spridas utanför klinikerna, till bakterier i miljön som har möjlighet att fungera som reservoarer för antibiotikaresistens. Oron har framförallt gällt akvatiska miljöer där resistensgener kan spridas naturligt med vattenflödet. Detta gäller i synnerhet avloppsreningssystem där avfall från det urbana samhället samlas upp och det renade avloppsvattnet släpps ut i ytvattnet. Ett ytterligare orosmoment i sammanhanget är att antibiotika som återfinns i avloppsvatten, utsläppt från sjukhus och från hushåll, tänkbart skulle kunna selektera fram resistenta bakterier.

Syftet med denna avhandling är att utreda effekterna av mänskliga utsläpp av antibiotika på antibiotikaresistensutveckling bland bakterier i vattenmiljöer. Påverkan på integroner, genetiska strukturer som har förmågan att sprida antibiotikaresistensgener mellan bakterier, undersöktes också. Vattenmiljöer opåverkade av mänskligt avloppsvatten, miljöer med låg förekomst av antibiotika (koncentrationsnivåer liknande de som vanligtvis återfinns $\mathrm{i}$ avloppsvatten), samt miljöer med väldigt högt antibiotikatryck undersöktes med avseende på förekomst av antibiotika, antibiotikaresistensgener och integroner. Detta för att etablera huruvida mänsklig påverkan på miljöerna leder till ökad spridning av antibiotikaresistensgener.

Inledningsvis uppmättes mängder av antibiotika, antibiotikaresistensgener och integroner i ett antal olika vattenmiljöer i Pakistan. Dessa områden inkluderade floder, en kanal, en damm samt nära industriområden där antibiotika tillverkas. Mätningarna visade att höga halter antibiotika i miljön åtföljdes av höga halter antibiotikaresistensgener och integroner. Särskilt utanför ett industriområde där antibiotika tillverkades återfanns ytterst höga halter av de uppmätta antibiotikumen och motsvarande resistensgener. Halterna av antibiotika, resistensgener och integroner befanns också öka signifikant i en flod då den rann igenom staden Lahore (med mer än tio miljoner invånare). Samma trend kunde ses då antibiotikaresistensgener och integroner uppmättes i den svenska floden Stångån. Halterna av dessa gener befanns öka då Stångån passerar och mottar renat avloppsvatten från Linköping. 
För att undersöka effekten under mer kontrollerade förhållanden tillsattes en blandning av olika antibiotikum till en serie av anlagda våtmarker i 25 dagar. Våtmarkerna var anlagda för att användas i experimentella syften och hade inte tidigare utsatts för antibiotika. Koncentrationerna av antibiotika som användes var ca tio gånger så höga som de som förväntas finnas i avloppsvatten. Mätningarna visade att ingen påverkan på den bakteriella mångfalden, mängden antibiotikaresistensgener eller mängden integroner kunde tillskrivas det tillsatta antibiotikumen. De anlagda våtmarkerna uppvisade dessutom en förmåga att rena vattnet från antibiotika, av ungefär samma grad som ett avloppsreningsverk. Den renande förmågan samt avsaknaden av antibiotikaresistensutveckling tyder på att anlagda våtmarker skulle kunna vara bra komplement till avloppsvattensrening.

För att undersöka effekterna av olika koncentrationer av antibiotika på en vattenmiljö opåverkad av avloppsvatten, samlades vatten och sediment ihop från Nydalasjön utanför Umeå. Vattnet och sedimenten delades upp i olika behållare till vilka tillsattes olika höga koncentrationer av antibiotika. Koncentrationerna sträcktes sig från ungefär vad som förväntas finnas i avloppsvatten, till 1000 gånger denna koncentration. Inte heller i detta experiment kunde någon påverkan från tillsatsen av antibiotika påvisas på antibiotikaresistensgener eller integroner, även då dessa återfanns i ursprungsmiljön.

Antibiotikaresistensgener och integroner förefaller finnas i vattenmiljöer i låga halter. Mänsklig påverkan i form av utsläpp av avloppsvatten och avfall tycks dock öka halterna av dessa. Antydningar till en direkt koppling mellan antibiotikaföroreningar och motsvarande antibiotikaresistensgener och integroner finns i miljöer förorenade med mycket höga halter av antibiotika. Däremot förefaller låga nivåer av antibiotikaföroreningar sakna direkt påverkan på halterna av antibiotikaresistensgener och integroner. För att kunna förhindra spridningen av antibiotikaresistens behövs ytterligare studier för att klargöra vilka halter av antibiotika som krävs för att antibiotikaresistens skall utvecklas och spridas i vattenmiljöer. 


\section{List of papers}

I. Khan, G.A., Berglund, B., Khan, M.A., Lindgren, P.E. and Fick, J. (2013) Occurrence and abundance of antibiotics and resistance genes in rivers, canal and near drug formulation facilities - a study in Pakistan. PLoS One. 8(6):e62712.

II. Berglund, B., Fick, J. and Lindgren, P.E. Detection and quantification of antibiotic resistance genes in Stångån River, Sweden. In manuscript.

III. Berglund, B., Khan, G.A., Weisner, S.E.B., Ehde, P.M., Fick, J. and Lindgren, P.E. (2014) Efficient removal of antibiotics in surface-flow constructed wetlands, with no observed impact on antibiotic resistance genes. Sci. Tot. Environ. 467-477C:29-37.

IV. Berglund, B., Khan, G.A., Lindberg, R., Fick, J. and Lindgren, P.E. Abundance and dynamics of antibiotic resistance genes and integrons in lake sediment microcosms. In manuscript.

Paper III is reprinted with permission from the publisher. 


\section{Abbreviations}

ARG Antibiotic resistance gene

DGGE Denaturing gradient gel electrophoresis

DHFR Dihydrofolate reductase

DHPS Dihydropteroate synthase

ESBL $\quad$ Extended spectrum $\beta$-lactamase

ESI Electrospray ionisation

ICE Integrative conjugative element

IS Insertion sequence

LC Liquid chromatography

LC-MS Liquid chromatography-mass spectrometry

LUX Light-Upon-eXtension

MGE Mobile genetic element

MIC Minimum inhibitory concentration

Mpf Mating pair formation

MRM Multiple reaction monitoring

MRSA Methicillin-resistant Staphylococcus aureus

MS Mass spectrometry

MS/MS Triple quadropole-mass spectrometer, Tandem mass spectrometer

oriT Origin-of-transfer

PCR Polymerase chain reaction

SNP Single nucleotide polymorphism

SPE Solid-phase extraction

WWTP Wastewater treatment plant

XDR Extensively drug resistant 


\section{Table of contents}

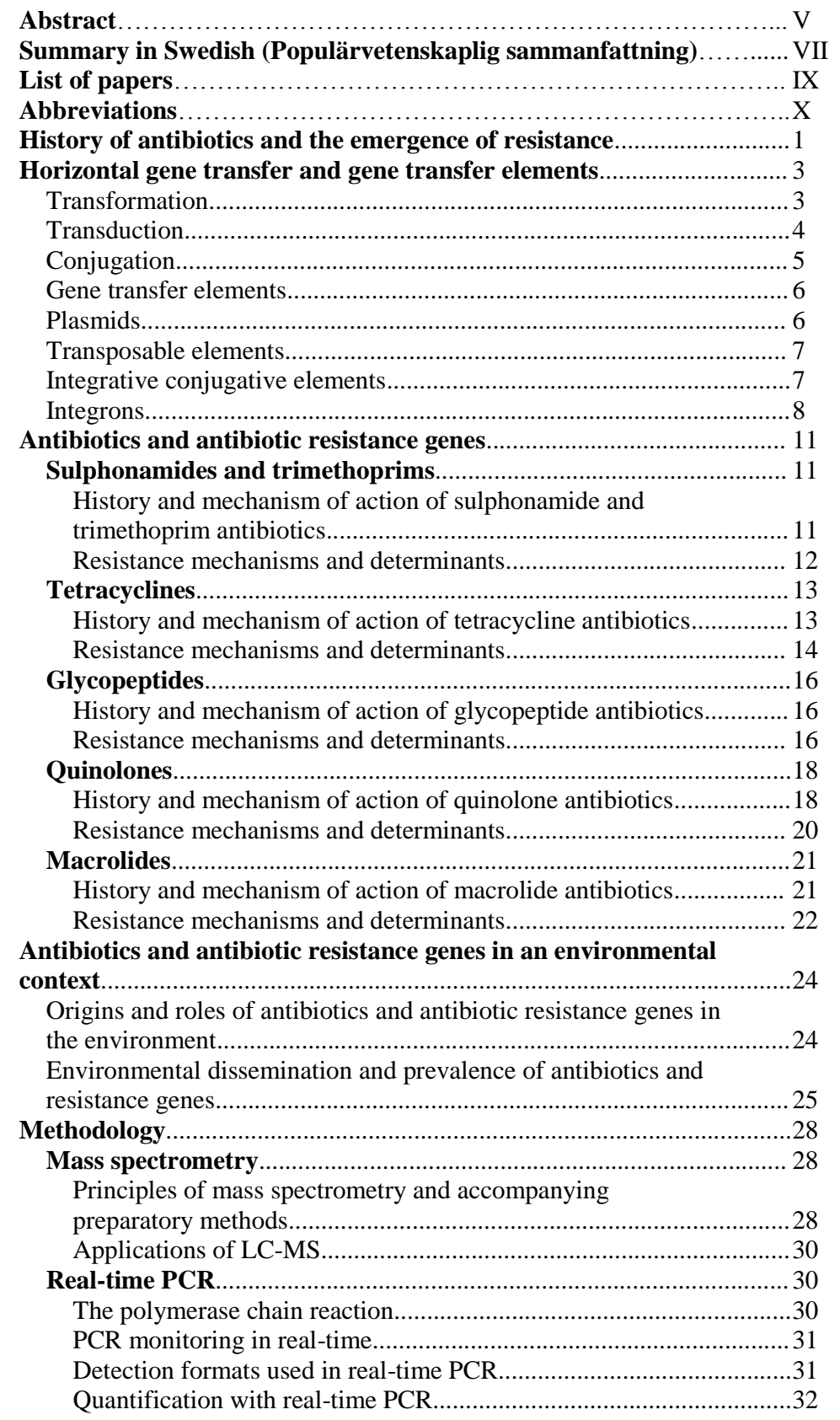




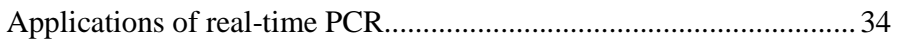

Denaturing gradient gel electrophoresis............................................ 34

The principles of denaturing gradient gel electrophoresis.................... 34

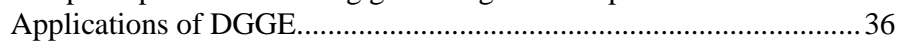

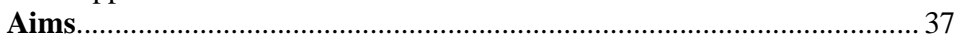

Antibiotics and resistance genes in water environments affected by human activities (Papers I \& II) ....................................................... 38

Removal and effect of low levels of antibiotics on surface-flow Constructed wetlands (Paper III) ......................................................... 43

Effect of different levels of antibiotics on a water environment previously unexposed to antibiotics (Paper IV).....................................4

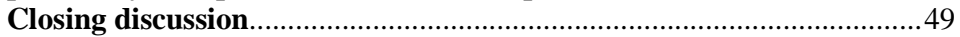

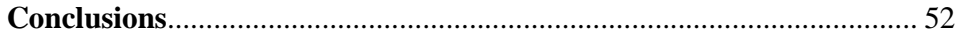

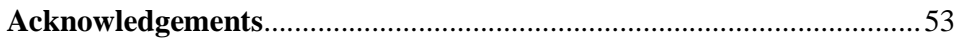

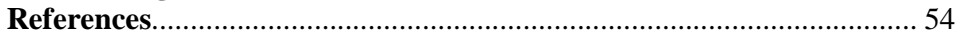




\section{History of antibiotics and the emergence of resistance}

The first antibiotic compound, penicillin, was discovered in 1928 by Alexander Fleming as a product of the fungus Penicillium notatum, and became available for therapeutic use in the 1940s. The therapeutic usage of penicillin was however pre-empted by another class of antibiotics, the sulphonamides, which were introduced in 1937 (Davies et al., 2010). The effect these new types of therapeutical agents had on the treatment of bacterial diseases cannot be overestimated. Not only did deadly infectious diseases become treatable, but the availability of antibiotics opened up possibilities for new kinds of medical interventions including major surgical interventions and organ transplants (Wright, 2010a). For some decades after their introduction, antibiotics seemed to have solved the problem of bacterial infectious diseases forever (Davies, 2010).

Although antibiotic resistant bacteria started to appear soon after the clinical introduction of antibiotics, the problem was limited and was at first dismissed as of little concern. Sulphonamide-resistant Streptococcus pyogenes appeared in hospitals as early as the 1930s and penicillin-resistant Staphylococcus aureus after penicillin had been introduced in the 1940s. In the 1950s, multi-drug resistant enteric bacteria started to cause problems (Levy et al., 2004). Furthermore, antibiotic resistance capable of being transferred horizontally between bacteria was discovered. The importance of horizontal gene transfer in the dissemination of antibiotic resistance was not to be appreciated until much later (Davies et al., 2010).

Overuse and misuse of antibiotics are widely regarded as having been major factors in promoting antibiotic resistance (Wright, 2010a). In clinical contexts, such misuses include prescription of antibiotics without the infection established to be bacterial (Allen et al., 2010) and patient non-compliance to the full prescription (Laxminarayan et al., 2006). These problems are further exacerbated in developing countries were socioeconomic factors dictate the handling of antibiotics. Self-medication is prevalent as antibiotics are often sold over-the-counter and a general lack of education and awareness prompts misuse of antibiotics (Planta, 2007; Wellington et al., 2013). Furthermore, since antibiotics are often sold pill-by-pill developing countries, poor patients are unlikely to fulfil their prescribed antibiotic regimens once they feel better due to economic reasons (Planta, 2007; Blomberg, 2008). Emergent antibiotic resistance in developing countries are also not necessarily regionally confined, since today's globalised world allows for resistant bacteria as well as people to travel around the world (Wright, 2010a). 
The great success of antibiotics in therapy prompted the compounds to be used outside of clinical contexts. Antibiotics began to be used in large scale as growth promoters and prophylactics in livestock, usually administered by addition to the feed (Phillips et al., 2004). This new kind of application also meant a massive environmental exposure of antibiotics (Allen et al., 2010). Other non-clinical uses of antibiotics in large scale include their usage in fish (Kümmerer, 2004) and poultry farming (Phillips et al., 2004). It is widely believed that this excessive use of antibiotics has contributed to the development and dissemination of antibiotic resistance. As a result, a number of antibiotics were banned for usage as growth promoters in the European Union in the 1990s (Phillips et al., 2004; Hawkey, 2008).

Today, antibiotic resistance is a well-acknowledged global problem. While antibiotics are still effective at treating many bacterial infections, some strains are extremely difficult to treat, and therapeutical options are getting increasingly fewer (Appelbaum, 2012). This is exacerbated by the fact that the short expected time of usefulness of a new antibiotic compound before resistance arises means that few companies are interested in developing new antibiotics for profit reasons (Davies, 2010). Recent rising threats to have appeared include; bacteria carrying extended spectrum $\beta$-lactamases (ESBL) which confer resistance to penicillins and many cephalosporins, extensively drug resistant (XDR) Mycobacterium tuberculosis, and multi-drug resistant Acinetobacter baumannii, Neisseria gonorrhea, Pseudomonas aeruginosa, and Enterobacteriaceae (Wright, 2010a). It has been estimated that in the European Union, antibiotic resistant bacteria are responsible for over 25,000 deaths every year (Aronsson et al., 2009). In short, antibiotic resistance is getting more prevalent and wider disseminated and few new antibiotics are in development. As the situation stands today, there is a clear risk that mankind will return to clinical conditions resembling those before the therapeutical advent of antibiotics (Appelbaum, 2012). 


\section{Horizontal gene transfer and gene transfer elements}

When a bacterial cell divides, the chromosome of the bacterium is passed on to its daughter cells. But apart from this vertical transfer, genetic information can also be passed between bacteria through processes known as horizontal gene transfer (HGT). The three main processes of horizontal gene transfer are transformation, transduction and conjugation.

\section{Transformation}

Some bacteria can obtain new genes by taking up DNA directly from the environment through a process known as transformation. More than 60 species of bacteria spread over seven phyla are known to be naturally transformable (Johnsborg et al., 2007). For a bacterium to be able to take up DNA by transformation, it must first enter a state known as competence. This state is characterised by an upregulation of genes expressing proteins necessary for the transformation process itself. For most of the naturally transformable bacteria which have been studied, competence is a transitional state (Chen et al., 2004). However, some species, for example N. gonorrhoeae, are always competent (Davison, 1999).

The process by which transformation occurs is similar in most bacteria, although some obvious differences exist between transformation in Gram-positive and Gram-negative bacteria owing to cell wall differences. Even between Gram-positive and Gram-negative bacteria however, the proteins involved are related to each other (Chen et al., 2004). The first step in transformation is for the free dsDNA to interact with the bacterial surface. In Gram-positives, a single strand of the DNA is transported across the cytoplasmic membrane while the complementary strand is degraded. In Gram-negatives, the dsDNA is taken across the outer membrane to the periplasm (Chen et al., 2005). In some Gram-negatives such as Haemophilus influenzae and Neisseria spp., a species-specific recognition sequence must be present in the DNA for efficient uptake into the periplasm. These sequences are common in that particular species' genome, which ensures that transformation of DNA from other individuals of the same species is favoured at the expense of foreign DNA (Chen et al., 2004). For all Gram-negatives, the transporting of the DNA into the cytosol is similar to how Gram-positives do it. Only a single strand of the DNA is transported across, while the complementary strand is degraded (Chen et al., 2005). 
For the recipient bacterium to be able to utilise the newly acquired genes, the DNA taken up must undergo recombination. The chance of the foreign DNA to undergo recombination is heavily dependent on how homologous the DNA is with the DNA of the recipient bacterium (Davison, 1999). This means that the recipient bacterium is more likely to acquire genes from closely related bacteria. However, it is still possible for the recipient bacterium to recombine more foreign DNA at lower frequencies by illegitimate recombination (Brigulla et al., 2010). In Domingues et al., 2012, it was shown that DNA carrying transposable elements (e.g. transposons) acquired through natural transformation can assist in the chromosomal incorporation via transposition events. Since transposable elements are often seen associated with antibiotic resistance determinants, natural transformation is likely play a bigger role in antibiotic resistance dissemination than previously conceived.

Transformation in the environment may intuitively sound like a rare event considering the sensitivity of DNA to degradation by nucleases and the dilution effects in water environments. However, DNA may be stabilised by adhesion to particles from sediment soil. Dilution effects may also be less important if transformation occurs in biofilms where newly deceased bacteria lyse and allow their neighbouring bacteria to take up their released DNA (Davison, 1999). Natural transformation has been demonstrated in many different environments, including marine water, ground water, rivers and soil (Davison, 1999), and has been implicated as responsible for the dissemination of penicillin-resistance genes in Streptococcus spp. (Johnsborg et al., 2009).

\section{Transduction}

Transduction is the transfer of DNA from the chromosome of one bacterium to another bacterium using bacteriophages as carriers of the DNA. It is common to distinguish between two conceptually distinct processes of transduction; generalised and specialised transduction. In generalised transduction, the packaging of DNA into the phage particle goes wrong and any part of the bacterial chromosome is packaged instead of the phage DNA. Whereas in specialised transduction, the prophage of a lysogenic virus gets erroneously excised from the chromosome together with bacterial DNA adjacent to its integration site in the chromosome. In both cases, the functional phage particles are loaded with bacterial DNA and spread from the host bacterium to infect new bacterial cells. After the DNA has been injected into the recipient bacterium, recombination must occur for the bacterium to be able to utilise the genes in question. As with transformation, homologous DNA is more likely to undergo recombination efficiently (Brigulla et al., 2010). 
Traditionally, the importance of transduction by bacteriophages in mediating antibiotic resistance has been considered to be of minor importance. However, recently their role has begun to be re-evaluated (Muniesa et al., 2013). Phage particles are well suited for mediating DNA transfer in the environment. Contrary to naked DNA, they are relatively resistant to environmental degradation and their compact size further simplifies their dissemination (Davison, 1999). Furthermore, some bacteriophages are known to have very broad host ranges, some even capable of infecting different bacterial classes (Jensen et al., 1998). These properties make bacteriophages ideal for transferring genes between spatially distant bacterial communities, such as from the environmental communities to human microbiomes (Muniesa et al., 2013). Transduction has been shown to be common in marine environments (Jiang et al., 1998). Furthermore, evolutionary studies have demonstrated that considerable parts of the bacterial genomes have prophage origins (Brüssow et al., 2002). Through viral metagenome analyses, $\beta$-lactamase genes have been detected in activated sludge and urban sewage (Rolain et al., 2012). The gene conferring methicillin resistance in methicillin resistant $S$. aureus (MRSA), mecA, has also been found in bacteriophage DNA from a wastewater treatment plant (WWTP) and the receiving water (Colomer-Lluch et al., 2011). As such, transduction may be an important mode of transfer in the environmental dissemination of antibiotic resistance genes (ARGs).

\section{Conjugation}

Conjugation is a mechanism which involves the direct transfer of DNA from one bacterial cell to another. The mechanism for mediating the cell-to-cell contact is different depending on the particular conjugation system used. Generally, in Gram-negatives the donor cell expresses a pilus which is used to attach to the recipient cell (Chen et al., 2005). In enterococci, recipient cells secrete pheromones which induce donor cells carrying a particular kind of plasmid to produce adhesins which form complexes with the donor cells (Grohmann et al., 2003). Regardless of the process used to initiate cell-to-cell contact, the processing of the DNA to be transferred appears to be an evolutionary conserved process. It begins with a relaxase enzyme nicking the DNA to be transferred at a site called the origin-of-transfer (oriT). A single DNA strand from the nick is then transferred to the recipient cell through a complex of proteins called the mating pair formation $(\mathrm{Mpf})$ which serves as a channel between the donor and recipient cell. Importantly, after a conjugation, both the donor and the recipient cell have a copy of the plasmid (Chen at al., 2005; Smillie et al., 2010).

Antibiotic resistance transferable by bacterial conjugation was discovered in the $1950 \mathrm{~s}$ (Davies et al., 2010). Since then, ARGs transferable by conjugation have been recorded numerous times. This has lead to conjugation being traditionally seen as the most 
important mechanism for horizontal gene transfer among bacteria. The benefits of this mode of transfer include the potential to transfer DNA among a broad host-range of species (Smillie et al., 2010). Conjugation has even been demonstrated from bacterial cells to eukaryotic cells (Bates et al., 1998), and has been seen in many different environments, including soil, marine sediment, seawater, sewage wastewater and activated sludge (Davison, 1999). The most important genetic elements capable of being transferred by conjugation are the plasmids and the integrative conjugative elements (ICEs) (Smillie et al., 2010).

\section{Gene transfer elements}

The nature of the genetic elements transferred is an important aspect of HGT. While chromosomally located genes certainly can be transferred in HGT, particularly by transformation and transduction, extrachromosomal and mobile genetic elements (MGEs) play a large role in facilitating bacterial diversity through gene transfer. Plasmids and ICEs are MGEs which can be transferred by conjugation. Other genetic elements of importance are the transposable elements which are capable of changing their genetic location in the bacterial cell, and gene capture elements such as integrons (Bennett, 2008).

\section{Plasmids}

Plasmids are typically double-stranded, circular, extrachromosomal DNA molecules which replicate autonomously and independent from the host bacterial chromosome. By definition, plasmids carry genes coding for non-essential functions, including genes coding for antibiotic resistance (Carattoli, 2011). Plasmids are the classical agents of conjugation. For a plasmid to be able to be transferred through conjugation, it must carry an oriT site. Plasmids which also carry all the other genes necessary for conjugation, including genes coding for the relaxase and the Mpf, are known as conjugative plasmids. In essence this means that they are self-sufficient in their transfer to other cells. They regulate their own transfer without any need for components provided from other genetic sources. On the other hand, plasmids which do not encode their own Mpf complexes are called mobilisable plasmids. This means that they are reliant on the Mpf complex encoded and expressed by other genetic sources (e.g. other plasmids) to be able to transfer themselves to a recipient cell. Aside from conjugative and mobilisable plasmids, there are also plasmids which are incapable of transfer by conjugation. These are called nonmobilisable plasmids and are transferred to other cells only by transformation or transduction (Smillie et al., 2010). 
Some plasmids are designated as having a narrow host range i.e. they are only transferable between bacteria of the same or closely related species. Broad host range plasmids on the other hand, can be transferred between many different species. Plasmids transferable to all species within a division, and even higher taxonomical levels have been observed. Many plasmids carrying ARGs have a broad host range, making them capable of transferring antibiotic resistance to a wide range of different bacteria (Bennett, 2008).

\section{Transposable elements}

Transposition is a process in which a gene moves from one location to another on a chromosome or a non-chromosomal element in the cell. Genetic elements capable of bringing about this relocation are called transposable elements. These include the insertion sequences (IS) and transposons. ISs are short DNA segments of a length generally less than $2,500 \mathrm{bp}$. Their capacity for transposition is mediated by a transposase which they encode, and inverted repeats which are located on both ends of the segment (Mahillon et al., 1998). Transposons are larger elements which often carry accessory genes, including antibiotic resistance determinants. Like ISs, transposons carry a gene coding for a transposase, which enables them to change location on their carrier element. While ISs and transposons are not necessarily conjugative, due to their nature, they have the potential to integrate into mobilisable or conjugative genetic elements (e.g. plasmids). This can, for instance, enable ARGs on a transposon to spread in a bacterial community. Transposition can also indirectly affect the host genome. For instance, genes close to a transposition site may be activated or inactivated, and flanking DNA may be subject of transduction (Curcio et al., 2003).

\section{Integrative conjugative elements}

Conjugative transposons, or ICEs, are another group of conjugative genetic elements (Roberts et al., 2008). They encode their own site-specific integration and excision from the bacterial chromosome in which they reside. Furthermore, ICEs encode their own conjugation machinery. Transfer of an ICE from one bacterial cell to another entails; excision of the ICE from the bacterial chromosome to form a circular DNA molecule, assembly of the Mpf complex, nicking of the ICE oriT, transfer of the DNA to the recipient cell, and finally integration into the chromosome of the recipient bacterial cell (Salyers et al., 1995; Burrus et al., 2002). ICEs carry accessory genes, which can be ARGs. ICEs of the Tn916 family for instance, are known to often carry the tetracycline resistance gene tet $M$, and are also often associated with non-conjugative transposons carrying macrolide-lincosamide-streptogramin B resistance gene ermB. Like many classes of 
MGEs, ICEs have a great potential for acquiring new accessory genes, which make them important to understand from a clinical perspective (Roberts et al., 2009).

\section{Integrons}

Integrons are genetic assembly platforms capable of capturing and expressing gene cassettes, which often encode antibiotic resistance determinants (Fig. 1). A defining feature of all types of integrons, is a gene coding for a site-specific tyrosine recombinase called an integrase. Integrases can excise and integrate gene cassettes into the integron primary recombination site (attI), which is located upstream of the integrase-coding gene (intI). Consecutive integrations of gene cassettes have led to integrons having an array of gene cassettes downstream of the attI site. Transcription of the gene cassettes are ensured by a promoter $\left(\mathrm{P}_{\mathrm{c}}\right)$ located in either intI or the attI site. Since gene cassettes are usually lacking in internal promoters, they are dependent on $\mathrm{P}_{\mathrm{c}}$ for expression. This in turn means that their expression is dependent on their order in the cassette array. The closer the gene cassette is to the attI site, the more likely it is to be expressed (Mazel, 2006; Cambray et al., 2010).

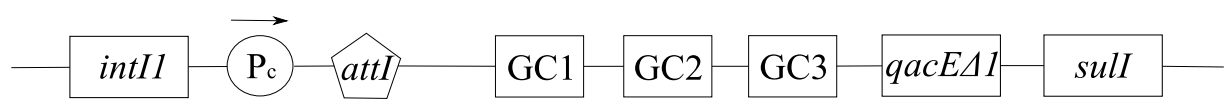

Figure 1. The basic structure of a class 1 integron. The gene intIl encodes a site-specific integrase which can excise and integrate gene cassettes at the site-specific integration site attI. In this example, the integron contains three gene cassettes denoted GC1, GC2 and GC3. Expression of the gene cassettes is induced by the promoter $\mathrm{P}_{\mathrm{C}}$. Class 1 integrons also consist of two conserved genes at the 3 '-end, quarternary ammonium compound resistance gene qacEA1 and sulphonamide resistance gene sulI.

Expression of intI is usually suppressed by the transcriptional repressor LexA. LexA is a repressor involved in the prokaryotic SOS response, and is autolytically cleaved when the cell is exposed to stress, such as DNA damage. In other words, the SOS response induces derepression and subsequent expression of the intI gene. The resulting integrase activity in turn means excision of gene cassettes, reshuffling of order, and possible addition of new gene cassettes to the integron. This means a change in the expressed phenotypes, and may possibly give the host bacterium an adaptive advantage in the face of the dangers which induced the SOS response. Interestingly, antibiotics such as trimethoprim, quinolones and $\beta$-lactams are known to induce the SOS response. Thus, bacteria carrying resistance gene cassettes on an integron, may have an inducible selective advantage when faced with antibiotic exposure (Guerin et al., 2009). The SOS response has also been shown to be inducible by conjugative DNA transfer, which means that integrons transferred to another 
host cell on a conjugative plasmid are likely to reshuffle their cassettes and thus increase the phenotype expression variability in a population (Baharoglu et al., 2010).

Integrons are typically divided into mobile integrons and chromosomal integrons. Mobile integrons are, as the name suggests, integrons which are readily disseminated between bacteria. While mobile integrons cannot mobilise and transfer themselves per se, they are often associated with genetic elements which can, such as plasmids (Mazel, 2006; Cambray et al., 2010; Domingues et al., 2012a). Recent studies have also indicated that natural transformation may be important in the dissemination of integrons (Domingues et al., 2012b). Mobile integrons are often capable of changing genetic locations within the host cell as well, since they are commonly associated with transposable genetic elements such as ISs and transposons (Domingues et al., 2012a). Class 1 integrons, a class of mobile integrons commonly found among clinical isolates, are associated with transposons derived from Tn402, which in turn can be carried by larger transposons, such as $\operatorname{Tn} 21$. Although mobile integrons usually only have a few gene cassettes in their cassette arrays, they often encode antibiotic resistance determinants and other phenotypes which give the host bacteria an adaptive advantage (Mazel, 2006; Cambray et al., 2010).

Chromosomal integrons are different from mobile integrons in that they are immobile, and located on the chromosome of the host bacterium. Furthermore, they can have a large number of gene cassettes in their cassette arrays. While most of the genes in chromosomal integrons are yet of unknown function, they do not usually appear to code for antibiotic resistance determinants. Chromosomal integrons have typically been found in proteobacterial species, including Vibrio spp., Pseudomonas spp. and Xanthomonas spp. but have also been found in the spirochaete Treponema denticola. Although chromosomal integrons do not appear to have a great role in dissemination of antibiotics, they are believed to have played a big role in bacterial evolution and the evolution of mobile integrons (Mazel, 2006; Cambray et al., 2010).

Integrons are ubiquitous in the environment, and the ability of integrons to excise and acquire new gene cassettes have led to the notion that the sum of all gene cassettes in a given environment constitute a metagenome which resident integrons can access. The number of different gene cassettes in $50 \mathrm{~m}^{2}$ soil has been estimated to be more than 2,000 (Michael et al., 2004). In Koenig et al., 2008, around 1,000 different integron gene cassettes were found in marine sediments. While the large majority of these environmental cassette genes encode unknown functions, their variety suggests that bacteria carrying integrons have a vast pool of functions to tap in order to adapt to changing conditions. In Wright et al., 2008, class 1 integron concentrations were found to be higher in aquatic environments contaminated with metal and antibiotics compared to unexposed environments. Likewise, in Gaze et al., 2011, it was shown that class 1 integrons were 
more abundant in detergent and antibiotic contaminated sewage sludge and pig slurry compared to unexposed agricultural soils. The capacities of mobile integrons to disseminate among bacteria, to confer adaptive advantages in changing conditions, and to utilise the environmental metagenome of gene cassettes, make them likely facilitators of environmental antibiotic resistance dissemination. 


\section{Antibiotics and antibiotic resistance genes}

\section{Sulphonamides and trimethoprims}

\section{History and mechanism of action of sulphonamide and trimethoprim antibiotics}

Sulphonamides are a class of synthetic antibiotics which were developed in the early 1930s, making them the first antibiotic compounds (Fig. 2). Trimethoprims, also a class of synthetic antibiotics, were developed late in the 1960s (Fig. 2). While sulphonamides and trimethoprims are two distinct antibiotic classes, they both inhibit the folic acid synthesis in bacteria, although at different steps of the biosynthetic pathway. To capitalise on their synergistic effect, they are often used in combination (Sköld, 2001).

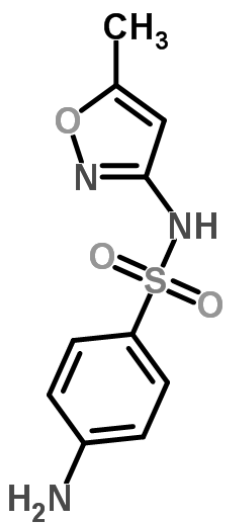

Sulfamethoxazole

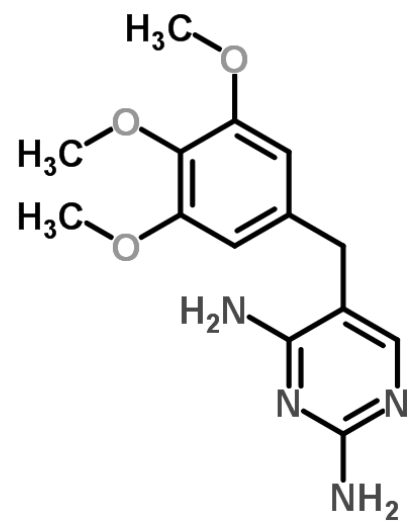

Trimethoprim

Figure 2. The chemical structures of sulfamethoxazole, a sulphonamide antibiotic, and trimethoprim. Image modified from www.ChemSpider.com.

Sulphonamides are inhibitors of the folic acid biosynthetic pathway. They act by binding competitively to the enzyme dihydropteroate synthase (DHPS). The function of this enzyme is to catalyse the synthesis of dihydropteroic acid, an essential component of the pathway, from the substrates $p$-aminobenzoic acid and 7,8-dihydro-6-hydroxymethylpterin-pyrophosphate (Fig. 3). Since mammalian cells obtain their folic acid by uptake from the environment instead of self-synthesis, they lack the enzyme which sulphonamides bind to. For this reason, mammalian cells (i.e. human cells) are unaffected by sulphonamides, making it possible to use the compounds 
therapeutically (Huovinen et al., 1995; Sköld, 2001; Hawser et al., 2006).

Like sulphonamides, trimethoprims also inhibit folic acid synthesis by competitive inhibition. However, trimethoprim inhibits a later step in the biosynthetic pathway, the reduction of dihydrofolate to tetrahydrofolate. This step is mediated by the enzyme dihydrofolate reductase (DHFR). Trimethoprim is a structural analog to the regular substrate, folic acid, and thus competitively inhibits the regular reaction by binding to DHFR (Fig. 3). While mammalian cells also use DHFR, their enzyme is distinct from the bacterial DHFRs. Trimethoprim lacks affinity for mammalian DHFR, making it possible to use it as an antibiotic for therapeutical purposes in humans (Huovinen, 1987; Sköld, 2001; Hawser et al., 2006).

\section{Resistance mechanisms and determinants}

Chromosomally encoded resistance has been found for both sulphonamides and trimethoprims. Point mutations in the gene coding for DHPS can result in an enzyme with less affinity for sulphonamides, resulting in resistance. Mutations in the gene coding for DHFR can by the same token decrease affinity for trimethoprim binding. Mutations in the regulatory region controlling expression of DHFR have also been observed. This leads to an overexpression of DHFR and thus increases the tolerance of the bacterium to the drug (Huovinen et al., 1995; Alekshun et al., 2007).

Resistance to sulphonamides is also known to be conferred by genes coding for DHPSs which lack affinity for sulphonamides. The most common of these genes are sulI and sulII, although a variant known as sulIII has also been found (Huovinen et al., 1995; Alekshun et al., 2007). Pei et al., 2006, found both sulI and sullI in river water from Colorado, USA. sulI and sulII have also been detected in Danish pigs (Wu et al., 2010), Australian and German surface waters (Stoll et al., 2012), and in freshwater and marine water in the Philippines (Suzuki et al., 2013). sull has also been found in wastewater (Gao et al., 2012). sulI is widespread in the environment, and since it is often found as a conserved part of class 1 integrons (Mazel, 2006), it can be expected to be found wherever these widespread MGEs are ubiquitous. sulII is most commonly found on plasmids of the inc $\mathrm{Q}$ group (Huovinen et al., 1995; Sköld, 2001).

Trimethoprim resistance has been found to be conferred by a large array of resistance genes. Over 20 different genes coding for DHFRs nonsusceptible to trimethoprims have been designated, with $d f r A l$ being the first found and also the most widespread. $d f r A l$ have been found as gene cassettes on both class 1 and class 2 integrons (Alekshun et al., 2007; Sköld, 2001). In general, $d f r$ genes appear to be commonly found on integrons as cassettes (Huovinen et al., 1995; Alekshun et al., 2007). 

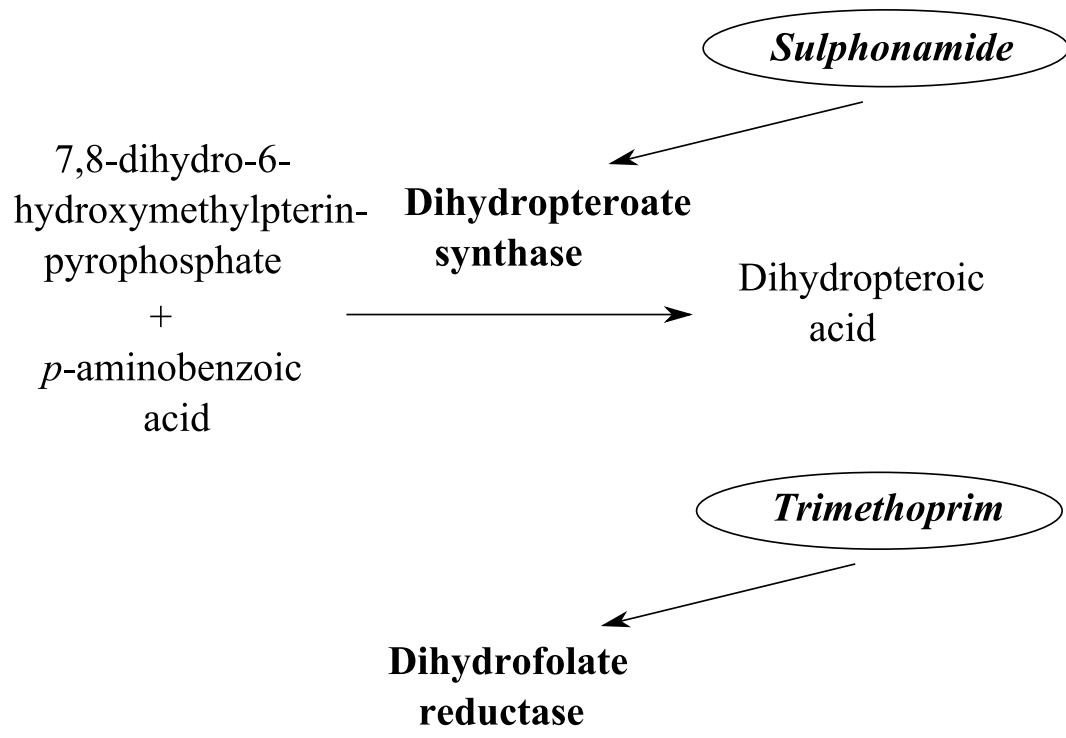

Dihydrofolate $\longrightarrow$ Tetrahydrofolate

Figure 3. Sulphonamides and trimethoprims inhibit different reactions of the folic biosynthesis pathway. Sulphonamides inhibit the enzyme DHPS which catalyses the formation of dihydropteroic acid.

Trimethoprims act on a reaction further down the pathway, by inhibiting the enzyme DHFR, whose function is to catalyse the reduction of dihydrofolate to tetrahydrofolate. In the figure, enzyme names are in bold and antibiotic names are in italics.

The $d f r$ genes' propensity for being carried on integrons is likely to have facilitated their widespread dissemination in the environment (Huovinen et al., 1995; Alekshun et al., 2007). In Mukherjee et al., 2006, dfrA1, dfrA5, dfrA6, dfrA12 and $d f r A 17$ were detected as cassettes in class 1 integrons in a river in India. In Portugal, dfrA1, dfrA7, dfrA12 and $d f r A 17$ were found as integron cassettes in a polluted lagoon (Henriques et al., 2006), and $d f r A 1$ and $d f r A 12$ were found in a WWTP connected to a slaughterhouse (Moura et al., 2007) and in surface waters from Germany and Australia (Stoll et al., 2012).

\section{Tetracyclines}

\section{History and mechanism of action of tetracycline antibiotics}

Tetracycline is a widely used class of antibiotics, and one of the first to be labelled as "broad-spectrum" antibiotics on virtue of their wide range of activity against both 
Gram-negative and Gram-positive bacteria. The first tetracycline, chlortetracycline, was discovered in the 1940s by chemical isolation from the soil bacterium Streptomyces aureofaciens. While the first tetracyclines available were isolated from Streptomyces spp., semi-synthetic tetracyclines were developed in the 1950s by chemical modification of the natural substrates (Chopra et al., 2001; Nelson et al., 2011).

The chemical structure common to all tetracyclines is the tetracyclic nucleus consisting of four hydrocarbon rings with varying functional groups attached to them (Fig. 4) (Chopra et al., 2001). The antibacterial functionality of tetracyclines is mediated by their ability to bind to the bacterial ribosome, thus preventing protein synthesis. More specifically, tetracyclines bind to the $30 \mathrm{~S}$ ribosomal subunit in the tRNA acceptor site region. This binding sterically hinders the aminoacyl-tRNA from coming into contact with the incoming mRNA, preventing translation (Chopra et al., 2001; Thaker et al., 2009).

Bacterial resistance against tetracyclines was discovered in less than a year after the discovery of the first tetracycline, although the mechanisms responsible were not elucidated until the 1970s (Nelson et al., 2011). Today, three mechanisms of gene-conferred resistance against tetracyclines are known; efflux, ribosomal protection and enzymatic inactivation (Nelson et al., 2011; Roberts, 2005).
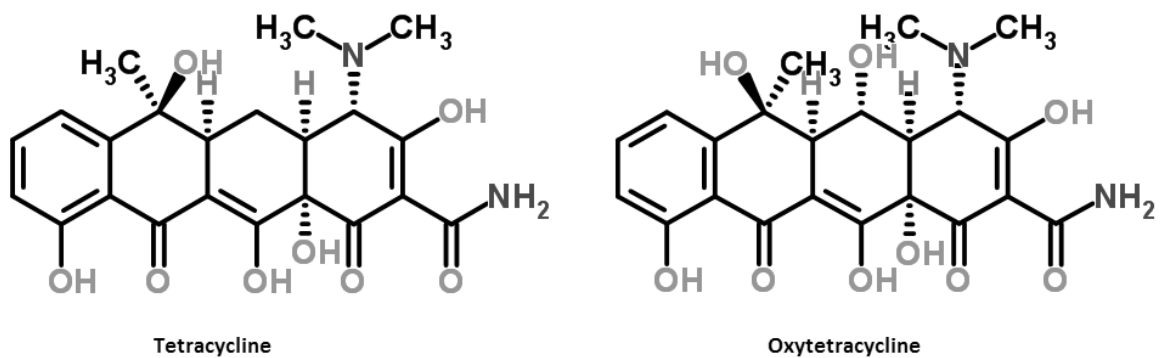

Figure 4. The chemical structures of two commonly used tetracycline antibiotics; tetracycline and oxytetracycline. Image modified from www.ChemSpider.com.

\section{Resistance mechanisms and determinants}

The majority of tetracycline resistance genes code for energy-dependent efflux pumps which reduces the intracellular concentration of the antibiotic. It is also the most common type of resistance gene among Gram-negative bacteria. Included among the efflux genes are tetA, tetB, tetC, tetD, tetK and tetL (Roberts, 2005). 
Ribosomal protection proteins are proteins which protect the bacterial ribosome from its interaction with tetracycline. By binding to the ribosome, the ribosomal protection protein confers a conformational change to the ribosome which disrupts the tetracycline binding site of the ribosome. Any bound tetracycline molecules are ejected from the ribosome, and protein translation may continue. Ribosomal protection protein genes are found among both Gram-negative and Gram-positive genera. Among the more common genes coding for this type of proteins are tetM and tetO (Thaker et al., 2009; Roberts, 2005).

Inactivation of tetracycline by enzymatic activity is a more rare type of tetracycline resistance mechanism. Only three genes coding for proteins capable of enzymatic inactivation of tetracyclines are known, tetX, tet34 and tet37 (Thaker et al., 2009; Roberts et al., 2005).

Tetracycline resistance genes have been encountered among many different bacterial genera among both Gram-positive and Gram-negative bacteria. tetA, tet $B$, tetC, and tetD for instance are found in Gram-negatives. tet $B$, for example, have been found in isolates of bacteria including $H$. influenzae, Moraxella catarrhalis and $T$. denticola. tet $K$ and tet $L$ on the other hand are widely disseminated among Gram-positives, and have been found in genera including Mycobacterium, Nocardia and Streptomyces (Chopra et al., 2001).

While many tetracycline resistance determinants are chromosomally encoded, the majority of tet genes are found on plasmids, transposons and ICEs. Many of the MGEs which carry tet genes are conjugative and also carry genes encoding resistance to other antibiotic compounds. For instance, tetM can be found on the ICE Tn2009 which also carries the macrolide-lincosamide-streptogramin B resistance gene ermB, and macrolide efflux genes $m e f A$ and $m f r D$. It is likely that great diversity of tet genes and the diversity and mobilisability of the genetic elements in which they reside have contributed significantly to their dissemination among many different bacterial genera (Roberts, 2005).

The tetracycline resistome, the sum of all available tetracycline resistance genes, is the biggest resistome known for any single antibiotic class, with the resistance genes being spread over many promiscuous conjugative genetic elements (Roberts, 2005; Thaker et al., 2009). It is then not surprising that tetracycline resistance genes have often been found when screened for in environmental contexts. Auerbach et al., 2007, found tetA, tetB, tetC, tetD, tetE, tet $G$, tetM, tet $O$, tet $S$ and tet $Q$ in wastewater from two WWTPs in Wisconsin, USA. Pei et al., 2006, found tet $O$ and tet $W$ in river water from Colorado, USA, and Knapp et al., 2010, detected tetB, tetL, tetM, tet $O$, tet $Q$ and tet $W$ in archived soil. Zhang et al., 2011, detected tetA, tetC, tet $G$, tet $M$, tet $S$ and tet $X$ in activated sludge from 15 different sewage treatment plants in China, and Stoll et al., 2012, found tet $A$ and tet $B$ in surface water from Germany and Australia. 


\section{Glycopeptides}

\section{History and mechanism of action of glycopeptide antibiotics}

Vancomycin, the first antibiotic of the glycopeptide class, was isolated from a soil sample from Borneo in the 1950s (Fig. 5). The substance was produced by the bacterium Streptomyces orientalis. Vancomycin initially showed a great deal of promise due to its effectiveness against most Gram-positive organisms. However, due to perceived toxicity and difficulty to administer (vancomycin usually must be administered intravenously) other newly developed antibiotics such as methicillin were soon favoured. Vancomycin was relegated to the role of a last resort antibiotic (Levine, 2006). Following the advent of MRSA and penicillin resistant Streptococcus pneumoniae in the 1980s, interest in the glycopeptide class of antibiotics has been renewed (Levine, 2006; Schilling et al., 2011). Other glycopeptides which are used today are teicoplanin, a glycopeptide compound isolated from Actinoplanes teichomyceticus in the 1970s (Jung et al., 2009) and telavancin (technically part of the lipoglycopeptide class of antibiotics), a newly approved synthetic derivate of vancomycin (Damodaran et al., 2011).

Glycopeptides work by inhibiting bacterial cell wall synthesis. This is facilitated by the glycopeptide binding to the D-alanine-D-alanine $\mathrm{C}$ terminus of the $\mathrm{N}$-acetylmuramyl-pentapeptide peptidoglycan precursor. This binding sterically hinders the nascent peptidoglycan from binding to the precursor, in turn preventing peptidoglycan cross-linking into the bacterial cell wall. Glycopeptides cannot cross the cell membrane into the cell. Therefore the binding to the peptidoglycan precursor takes place when the precursor molecule has been translocated across the membrane (Courvalin, 2006; Bugg et al., 2011).

\section{Resistance mechanisms and determinants}

Resistance to glycopeptides is provided by operons which principally code for two functions. Firstly, the glycopeptide resistance operon consists of a gene which codes for an enzyme which provides an alternative synthesis pathway for the D-alanine-D-alanine C terminus of the peptidoglycan precursor which the glycopeptides ultimately bind to. Instead, the C terminus will terminate with a D-lactate or a D-serine (depending on which gene resides in the operon). These structures have a significantly lower affinity for glycopeptides than the D-alanine terminus, providing the bacterium with peptidoglycan precursors which can escape the glycopeptides' inhibition and form complete peptidoglycans. Enzymes catalysing the alternative ligation processes resulting in D-lactate termini include those coded for by the vanA, vanB and vanD genes whereas vanC, vanE 
and $v a n G$ code for ligases responsible for creating D-serine termini (Courvalin, 2006).

For a bacterium to be properly resistant to glycopeptides, the glycopeptide susceptible peptidoglycan precursor molecules must also be eliminated. Genes (such as vanX and vanY) coding for enzymes capable of degrading susceptible precursor molecules are usually present on the glycopeptide resistance yielding operons (Courvalin, 2006).

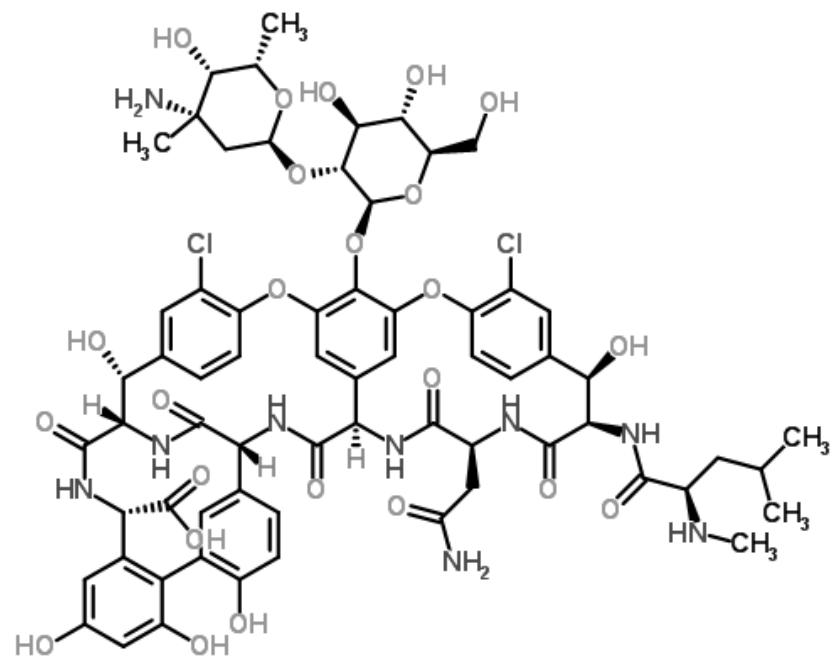

Vancomycin

Figure 5. The chemical structure of vancomycin, the first antibiotic of the glycopeptide class to be discovered. Image modified from www.ChemSpider.com.

Regulatory genes are also present on the glycopeptide resistance operons. Thus, the regulation of the expression of glycopeptide resistance differs between different operons. For example, expression of vanA-type operons is induced by the presence of vancomycin and teicoplanin while vanB-type operons are induced by vancomycin, but not by teicoplanin. vanD-type resistance on the other hand, is chromosomally located and expressed constitutively (Courvalin, 2006).

Enterococci are the archetypal glycopeptide resistance harbouring bacteria, and vanA and $v a n B$ (to a lesser extent) are the most common resistance types associated with them. The first type of vancomycin resistance found was of the vanA-type and was found in 
Enterococcus faecium. Subsequent findings of vanA have been in several Enterococcus spp., however predominantly in E. faecium and Enterococcus faecalis. E. faecium is also the species most commonly associated with $\operatorname{van} B$, although this type of resistance has also been found in other enterococci (Werner et al., 2008).

Although vancomycin-resistant enterococci are a significant clinical problem (Werner et al., 2008), more alarmingly is the potential of particularly vanA-type resistance to be transferred to $S$. aureus. Vancomycin-resistant $S$. aureus have only been isolated at a few occasions, however, at least some of the isolates proved to also be methicillin-resistant. A more widespread dissemination of this kind of multiresistant $S$. aureus have not yet occurred, but the mere potential of it should be the cause of major concern (Périchon et al., 2009).

The vanA operon is typically found to be carried on $\operatorname{Tn} 1546$ or $\operatorname{Tn} 1546$-like elements. While the former is nonconjugative, the latter are often found on conjugative plasmids. Dissemination of the $v a n B$ operon is believed to be mainly due to the spread of Tn916-like ICEs and related elements carrying the gene cluster (Courvalin, 2006).

Both vanA and vanB have been found in wastewater in England (Caplin et al., 2008) and Sweden (Iversen et al., 2002). Additionally, vanA and vanB have been found in meat from swine and bovine sources (Messi et al., 2006), and in marine water in the US (Roberts et al., 2009). vanA has also been found in wastewater in Portugal (Araújo et al., 2010), and wastewater and drinking water in Germany (Schwartz et al., 2003). Poultry have been particularly well-studied in regards to vancomycin resistance prevalence, and vanA has been found poultry from Norway (Borgen et al., 2000) and Sweden (Nilsson et al., 2012). Interestingly, a variant of the vanA operon has also been found in 30,000-year-old Beringian permafrost (D'Costa et al., 2011), which suggests that vancomycin resistance is both ancient and widespread in the environment.

\section{Quinolones}

\section{History and mechanism of action of quinolone antibiotics}

The first quinolone to see clinical use, nalidixic acid, was patented in the 1960s. It was discovered as a byproduct of the synthesis of the antimalarial compound chloroquine. The use of nalidixic acid was limited to treatment of urinary tract infections due to its low oral absorption and serum uptake levels as well as a narrow spectrum of activity against bacteria. Derivates based on nalidixic acid saw a broader spectrum of usage however. Norfloxacin, which was synthesised and patented in the late 1970 s, had activity against 
many Gram-negative as well as a few Gram-positive bacteria. Its development marked the beginning of a surge of newly invented and improved quinolones (e.g. ciprofloxacin). Despite the fact that many of the quinolones from this era are still used extensively in the clinic, new quinolones with improved pharmacokinetic profiles and spectra of antibacterial activity have steadily been developed to this day (Fig. 6) (Appelbaum et al., 2000).

Bacteria need to compress their DNA in order for it to fit in their relatively small cells. At the same time, the genes on the bacterial chromosome must at times be spatially available for expression and replication. This balancing act is regulated by topoisomerases. These enzymes are responsible for supercoiling of the DNA as well as unwinding and relaxing the tensions introduced in the chromosome due to the manipulation necessary to compress and decompress parts of it intermittently (Hawkey, 2003). Two pivotal topoisomerases are DNA gyrase and topoisomerase IV. DNA gyrase has the ability unwind DNA by introducing negative supercoils into the DNA helix. This is done by forming a complex with the DNA, transiently nick it, pass a single DNA strand through it, and reseal the break. The main function of topoisomerase IV is to release the two chromosomes from each other after replication (Froelich-Ammon et al., 1995; Hawkey, 2003).
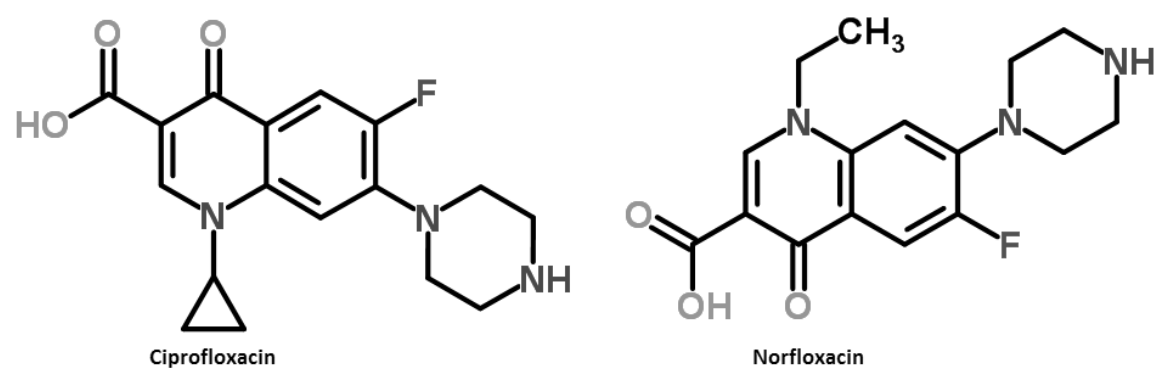

Figure 6. The chemical structures of two commonly used quinolone antibiotics; ciprofloxacin and norfloxacin. Image modified from www.ChemSpider.com.

DNA gyrase and topoisomerase IV must bind to and form complexes with DNA in order for them to facilitate their function. It is to these complexes that quinolones bind. The formation of the quinolone-topoisomerase-DNA complex induces conformational changes in the topoisomerase, preventing the cleaved DNA from being re-ligated. Thus, deadly nicks in the DNA are accumulated (Froelich-Ammon et al., 1995; Hawkey, 2003). 


\section{Resistance mechanisms and determinants}

Resistance to quinolones is most commonly obtained by an accumulation of point mutations in the genes coding for DNA gyrase and/or the genes coding for topoisomerase IV (Froelich-Ammon et al., 1995; Rodríguez-Martínez, 2011). Another common mechanism of quinolone resistance is mutations which lead to upregulation of efflux systems and downregulation of porins, decreasing the intracellular concentration of the quinolones (Robicsek, 2006). However, plasmid-mediated resistance to quinolones has recently been discovered (Martínez-Martínez et al., 1998). The first quinolone resistance proteins discovered, were the Qnr proteins, which are members of the pentapeptide repeat family (Strahilevitz et al., 2009). The mechanism by which Qnr proteins confer resistance to quinolones has not yet been fully elucidated. It is known that the proteins have neither degrading enzymatic activity nor efflux capacities. Instead, they appear to be able to bind to DNA gyrase and topoisomerase IV, and at least in the case of DNA gyrase, hinder it from binding to DNA. This in turn stops quinolones from binding in to the gyrase-DNA complex preventing the deadly nicks to accumulate. It is unknown however, how the Qnr protein can prevent the binding of DNA to DNA gyrase and still allow the bacterium to maintain topoisomerase activity (Robiscek et al., 2006; Strahilevitz et al., 2009).

Today, there are five known quinolone resistance genes coding for Qnr proteins, qnrA, $q n r S, q n r B$, qnrC and $q n r D$ (Strahilevitz et al., 2009). The $q n r$ genes and their variants have been found in clinical settings in countries all over the world, including the US (Robicsek et al., 2006), Bolivia (Pallecchi et al., 2009), Spain (Lavilla et al., 2008), China (Xu et al., 2007) and Kuwait (Cattoir et al., 2007). The bacteria from which they have been isolated include clinically important Enterobacteriaceae such as Escherichia coli, Klebsiella spp., Enterobacter spp., Citrobacter freundii and Providencia stuartii (Strahilevitz et al., 2009). There is also one case known of a qnrA-producing A. baumannii, isolated from an Algerian hospital (Touati et al., 2008).

The first quinolone resistance gene discovered, qnrA, was found to be carried on the plasmid pMG252. Since then, many $q n r$ genes have been found associated with plasmids and related MGEs. qnrA and $q n r B$ are often found on class 1 integrons, making quinolone resistance a trait often associated with other resistance determinants co-carried on the integron (Robiscek et al., 2006).

$q n r$ genes have on occasion been isolated from environmental sources. qnrS appears to be the most environmentally ubiquitous of the $q n r$ genes. It has been isolated from several different sources, including the activated sludge of a WWTP in Germany (Bönemann et al., 2006), from the river Seine in France (Cattoir et al., 2008), a lake in Switzerland (Picão et al., 2008) and river water in Turkey (Ozgumus et al., 2009). Other studies have found other 
genes, such as $q n r B$ in wastewater effluent from a WWTP in Italy (Forcella et al., 2010). $q n r B$ and $q n r S$ have been found in Mexican soils irrigated with wastewater (Dalkmann et al., 2012), and $q n r A, q n r S$ and $q n r B$ have been found in an urban coastal wetland close to the US-Mexico border (Cummings et al., 2011).

\section{Macrolides}

\section{History and mechanism of action of macrolide antibiotics}

The macrolide class of antibiotics is an old and commonly used antibiotic class (Fig. 7). Erythromycin, the first macrolide discovered, was isolated from a culture broth of Saccharopolyspora erythraea in 1952, and is still the most used macrolide today. Since the 1950 s, several macrolides have been isolated from culture broths of various different bacteria as well as created semi-synthetically (Kirst, 2001). Macrolides are characterised by a fairly broad spectrum of activity against bacteria. Bacteria against which erythromycin is effective include Bordetella pertussis, Corynebacterium diphtheriae, Legionella pneumophila, Listeria monocytogenes and Chlamydia. Semi-synthetic macrolides, such as azithromycin and clarithromycin, have a broader spectrum of activity (Roberts, 2004).

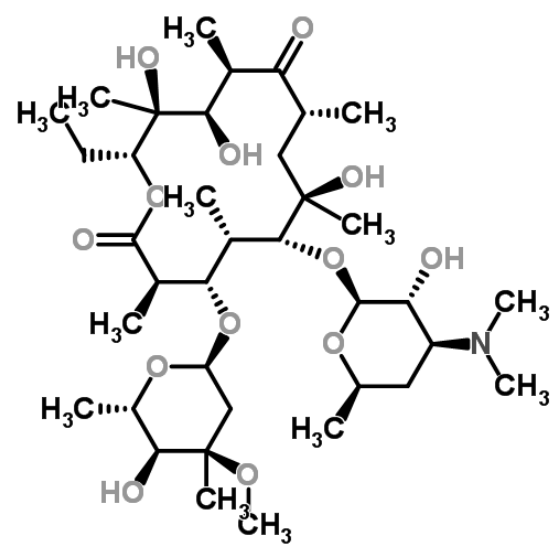

Erythromycin

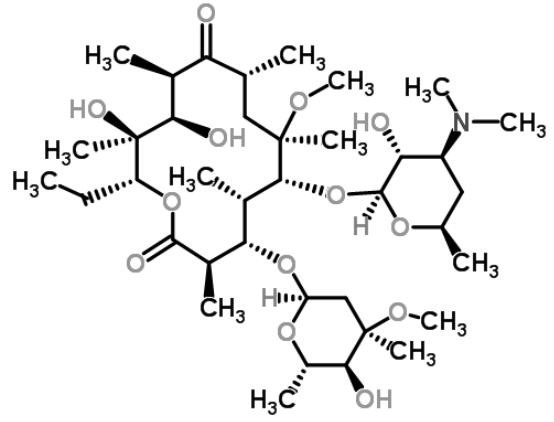

Clarithromycin

Figure 7. The chemical structures of two commonly used macrolide antibiotics; erythromycin and clarithromycin. Image modified from www.ChemSpider.com. 
Macrolides are protein synthesis inhibitors. They prevent peptide elongation by binding to the bacterial 50S ribosomal subunit (Roberts, 2004). Resistance to macrolides can arise by point mutations in either the $23 \mathrm{~S}$ rRNA gene or the genes coding for ribosomal proteins L4 and L22. Either of these mutations prevents macrolides from binding to the 50S ribosomal subunit. Point mutations in genes responsible for regulation of intrinsic efflux pumps can also lead to an upregulation of efflux activity, in turn leading to resistance (Roberts, 2008).

\section{Resistance mechanisms and determinants}

Macrolide resistance genes generally fall into three categories, rRNA methylases, efflux pumps and inactivating enzymes. The rRNA methylases confer resistance to macrolides by adding one or two methyl groups to the $23 \mathrm{~S}$ rRNA, which prevents the macrolides from binding to the $50 \mathrm{~S}$ ribosomal subunit. The rRNA methylases are encoded by the erm genes of which over 30 are known, making them the most numerous group of macrolide resistance genes. Some erm genes are widely disseminated among many different bacterial genera. For instance, ermB has been found in over 30 different genera, both Gram-negative and Gram-positive. Other erm genes are found only as innate genes in a single genus. Streptomyces and Mycobacterium each have rRNA methylase genes found only in their respective genera, and for Mycobacterium some are even species-specific (Roberts, 2008).

Efflux pumps are the most common macrolide resistance genes after the rRNA methylases. Like the rRNA methylases, some of the efflux pump genes are widespread among many genera, whereas others are found only in a single genus. mefA is the most widely disseminated of these genes and has been found in over 20 genera, whereas genes such as carA and $l s a A$ have only been find in a single genus respectively (Roberts, 2004; Roberts 2008). Enzyme-encoding genes which confer macrolide resistance include the ere genes and the $m p h$ genes. ere $A$ and $e r e B$ encode esterases and have been found in 11 and 8 genera respectively including Pseudomonas and Staphylococcus. $m p h A, m p h B$ and $m p h D$ encode phosphorylases and have been found in different Gram-negative genera including Proteus and Pseudomonas, whereas $m p h C$ have been found in both Gram-positives and Gram-negatives (Roberts, 2008).

$\mathrm{ermB}$ is the most widespread of the macrolide resistance genes, and it is linked with a variety of different MGEs including ICEs located on both chromosomes and plasmids as well as nonconjugative transposons (Roberts, 2008). The ICEs among which ermB has been found to be carried include $\operatorname{Tn} 1545$, Tn2010 and others of the Tn916 family, meaning that $\operatorname{ermB}$ is often linked with other antibiotic resistance determinants on a conjugative platform (Roberts, 2008; Roberts et al., 2009). 
erm genes are prevalent in the environment, and have been found in a variety of different environments. ermA and ermB have been found in milk from cows in Brazil (Duarte et al., 2004) and in poultry production environments along the eastern seaboard of the US (Hayes et al., 2005). Additionally, ermB have been found in poultry samples (Novais et al., 2005), wastewater in Portugal (Araújo et al., 2010) and German and Australian surface waters (Stoll et al., 2012). In Chen et al., 2007, ermA, ermB, ermC, ermF, ermT and ermX were found in bovine and swine manure as well as a swine waste lagoon. The phosphorylase gene $m p h A$ has been found in activated sludge of a WWTP (Szczepanowski et al., 2004). 


\section{Antibiotics and antibiotic resistance genes in an environmental context}

Since antibiotic resistance causes problems when it complicates the treatment of ill patients, it has historically mainly been studied in the context of clinical settings (Martínez, 2008). However, aside from resistance conferred by mutations, the source of antibiotic resistance determinants in pathogenic bacteria must have originated in non-clinical environments (Martínez, 2012). Recently, much more attention has been directed at understanding the ecological and environmental processes involved in resistance gene acquisition in pathogenic and environmental bacteria. While some examples linking ARG dissemination between the two exists (Wright, 2010b) the complexity and relative scarcity of studies done, means knowledge is still lacking in the field. Indeed, it is still unclear what role antibiotics normally play in the social context of the environmental bacterial community (Davies et al., 2010).

\section{Origins and roles of antibiotics and antibiotic resistance genes in the environment}

Antibiotics were originally discovered as compounds produced by environmental fungi and bacteria capable of killing off other microorganisms. Since these compounds were efficient at eradicating bacteria, it was generally assumed that the purpose of antibiotic production was to stave off competing microorganisms. On the same note, when ARGs were discovered, they were believed to have evolved in bacteria producing the antibiotics and target bacteria in order to protect against the effects of antibiotics (Martínez, 2009; Allen et al., 2010). While this point of view is not necessarily wrong, recently other aspects of the environmental functions of antibiotics have begun to be explored. The antibiotic concentration levels produced by environmental bacteria are commonly far the below minimum inhibitory concentrations (MICs), which suggests antibiotics may primarily serve some other function (Davies, 2006; Aminov, 2009). Evidence suggests that subinhibitory doses of antibiotics play several roles in the environment as regulatory substances and signaling molecules in inter-bacterial communication (Martínez, 2009; Allen et al., 2010; Sengupta et al., 2013). Interestingly, subinhibitory concentrations of various antibiotics have been shown to induce different states in bacteria, including biofilm formation, the SOS response, and changes in primary metabolism. These states can increase tolerance to antibiotics (Bernier et al., 2013). ARGs have also likely evolved to fulfil other purposes than protecting bacteria from antibiotics. One possibility is that the primary functions of ARGs in the environment are to regulate the responses induced from subinhibitory concentrations of antibiotics (Allen et al., 2010). Some ARGs may play regulatory roles in the biosynthesis of antibiotics, on example being $\beta$-lactamases, which 
have been suggested to at one point have been enzymes involved in peptidoglycan synthesis (Martínez, 2009). It is worth pointing out, that even though antibiotics and ARGs seem to have functions unrelated to antibiosis in the natural environment, it has been demonstrated that subinhibitory concentrations of antibiotics, about 200 times below MIC-values, can select for antibiotic resistant bacteria (Andersson et al., 2012).

While ARGs in their environmental context may originally have had other primary functions aside from conferring resistance to antibiotics, these genes have now been recruited as resistance genes in pathogenic bacteria. Furthermore, environmental bacteria harbour an as of yet unexplored pool of genes which may be found to have a new use as ARGs if passed on to pathogens which frequently encounter high, therapeutical levels of antibiotics. ARGs have existed since before humans started to use antibiotics in therapy, and they have likely existed for as long as antibiotics themselves have existed. In D'Costa et al., 2011, ARGs encoding resistance to $\beta$-lactams, tetracyclines and glycopeptides were reported to have been found in 30,000-year-old Beringian permafrost. Bhullar et al., 2012, found ARGs in a region of a cave in New Mexico which had been isolated for over 4 million years. Seeing as how antibiotics and ARGs have existed over such a long period of evolutionary time, it seems likely that the environment is a reservoir of potential ARGs from which pathogenic bacteria may recruit protection against therapeutical agents used against them by humans. Elevated levels antibiotics in the environment are likely to exacerbate the intensity of this recruitment.

\section{Environmental dissemination and prevalence of antibiotics and resistance genes}

Antibiotics of human origin can enter the environment through a number of different routes (Fig. 8). From hospitals, antibiotics and their metabolites are released with urine and faeces from patients as hospital wastewater effluent. Likewise, antibiotics are released into the wastewater treatment system from people taking their antibiotic prescriptions from home. From the WWTPs, the antibiotics can end up in sludge dispersed on fields as fertilizer, or released as run-off directly into the receiving surface waters (Halling-Sørensen et al., 1998; Segura et al., 2009; Hughes et al., 2013). Wastewater can also be treated by releasing it into wetlands (Scholz et al., 2005), in which case the antibiotics will also pass through there before ending up in surface and ground waters. Antibiotics are also used therapeutically or as growth promoters in livestock and poultry. Antibiotics and their metabolites will spread through animal excrements and end up in fields and ground water, or in the case of antibiotic use in fish farms, directly into the aquatic environment (Halling-Sørensen et al., 1998). It is also worth noting, that wherever antibiotics are spread, it is also likely that resistant bacteria follow the same routes of dispersal (Baquero et al., 2008). This results in environments where antibiotics, ARGs, resistant bacteria and the environmental bacterial 
flora, which may also harbour ARGs and potential ARGs, are mixed. These types of environments are likely resistance hotspots where ARGs proliferate and new resistant strains are created by HGT. When these resistant bacteria enter humans, they have the opportunity to spread their ARGs to the human microbiome. The routes by which humans may come into contact with these bacteria are numerous. They include consumption of crops grown by contaminated sludge used as fertilizer, drinking of water drawn from contaminated ground or surface water and frolicking in marine water linked to contaminated surface water (Wellington et al., 2013).

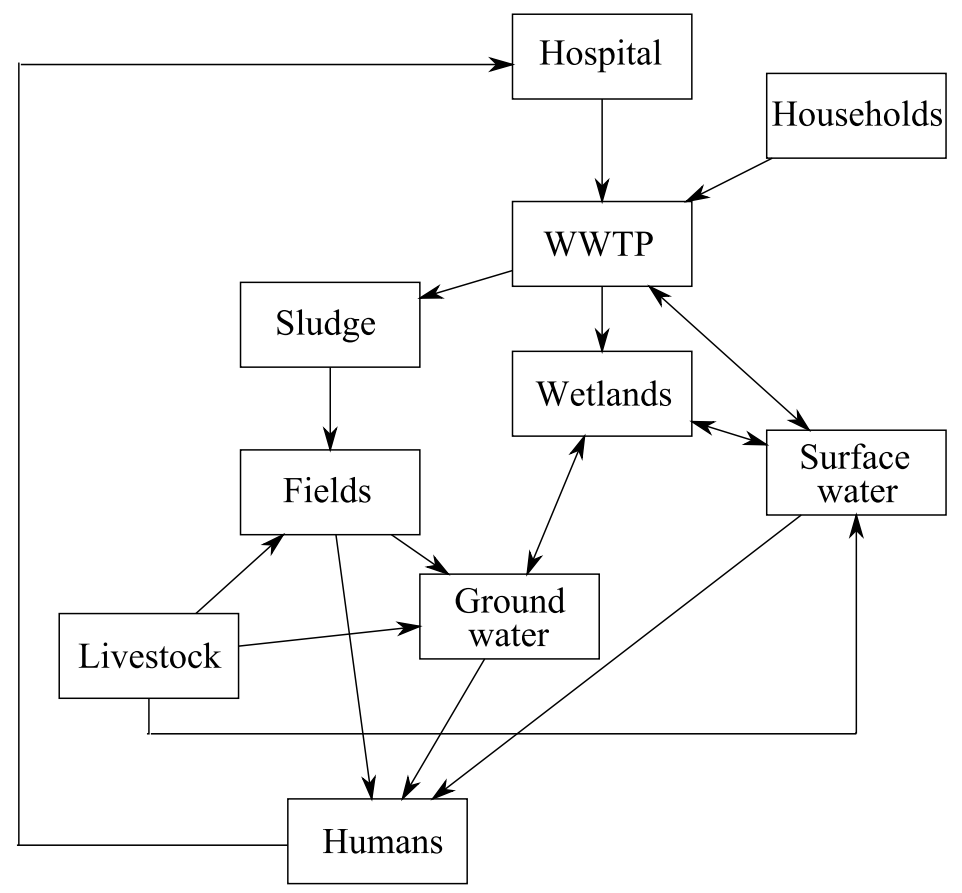

Figure 8. Antibiotics and ARGs genes can enter and remerge in humans via the environment by a number of different routes. Antibiotics and ARGs are excreted with urine and faeces from hospital patients and from patients taking antibiotic prescriptions at home. By both routes, the excrements will end up in a WWTP. Antibiotics and ARGs can by this route end up directly in surface water or ground water via an additional water treatment step in a wetland. Wastewater sludge containing antibiotic residues and ARGs can end up as fertilizer on fields, which can further seep into ground water by for instance rain. Livestock treated with antibiotics, either prophylactically or as a growth promoter, will contaminate fields with antibiotic residues and ARGs. The ARGs can end up in humans by for example, drinking water which comes from contaminated ground or surface water, engaging in recreational activities in contaminated surface water, or by eating crops grown from contaminated fields. Note how the commixture of antibiotics, ARGs and resident environmental bacteria provide an ideal opportunity for ARGs to develop and disseminate in the bacterial community. 
Antibiotic concentrations in aquatic environments have been generally found to range from low $n g \times \mathrm{L}^{-1}$ to $\mu \mathrm{g} \times \mathrm{L}^{-1}$ levels (Gros et al., 2006; Segura et al., 2009; Hughes et al., 2013). In Segura et al., 2009, studies reporting antibiotic concentrations in aquatic environments including surface, ground and wastewaters, were summarised. Median concentrations in surface and ground water were reported as $30 \mathrm{ng} \times \mathrm{L}^{-1}$ and $71 \mathrm{ng} \times \mathrm{L}^{-1}$ respectively. Antibiotic concentrations in wastewater were largely dependent on the source of the waste. For hospital wastewaters, a median concentration of $2,100 \mathrm{ng} \times \mathrm{L}^{-1}$ was reported and for urban wastewaters the median concentration was found to be $300 \mathrm{ng} \times \mathrm{L}^{-1}$. It is unknown what effect such levels of antibiotics have on bacteria in the environment. Gullberg et al., 2011, showed that resistant bacteria could be selected for in vitro at very low antibiotic concentrations. For the strains used, this corresponded to $15,000 \mathrm{ng} \times \mathrm{L}^{-1}$ for tetracycline and from 2,500 $\mathrm{ng} \times \mathrm{L}^{-1}$ to as a low as $100 \mathrm{ng} \times \mathrm{L}^{-1}$ for ciprofloxacin depending on what mutation the particular strain carrying. It is likely that the concentrations necessary for selection in a complex environmental community is different than compared to in vitro experiments. Regardless, it suggests that adverse effects of antibiotic contamination may come about even at concentrations ubiquitous in wastewater.

Extremely high concentrations of antibiotics have been reported in wastewater connected to antibiotic manufacturing facilities. Oxytetracycline concentrations in wastewater effluent from a WWTP treating waste from an oxytetracycline manufacturing facility in China was found to be as high as $20,000,000 \mathrm{ng} \times \mathrm{L}^{-1}$. Oxytetracycline concentrations in the receiving river were as high as $640,000 \mathrm{ng} \times \mathrm{L}^{-1}$ ( $\mathrm{Li}$ et al., 2008). Comparisons between bacterial strains isolated downstream and upstream of the oxytetracycline waste discharge point indicated that strains isolated downstream of the discharge point frequently had significantly higher MICs to seven different antibiotic classes. They were also more frequently multi-drug resistant and many different tet genes were detected in downstream isolates (Li et al., 2010). High concentrations of antibiotics have also been found in effluent from a WWTP treating wastewater from a large antibiotic manufacturing site in India. Ciprofloxacin was found in concentrations as high as $31,000,000 \mathrm{ng} \times \mathrm{L}^{-1}$, more than 1,000 times the lethal concentration for some bacterial strains and higher than therapeutic levels in human plasma (Larsson et al., 2007). ARGs were found to be more abundant in the water downstream of the production site than upstream (Kristiansson et al., 2011).

Even in environments with more modest levels of antibiotic contamination, there have been implications that contamination levels correlate with ARG abundance. In Pei et al., 2006, a higher abundance of ARGs was reported at anthropogenically impacted sites of a river in Colorado, USA, compared to pristine sites upstream. Integrons are suspected to play a major role in disseminating ARGs and several studies have shown that integron concentrations are higher in polluted environments (Wright et al., 2008; Rosewarne et al., 2010; Gaze et al., 2011). 


\section{Methodology}

In the works herein, three main analytical methodologies were used. Liquid chromatography-mass spectrometry (LC-MS) was used for detection and quantification of antibiotic compounds. Real-time polymerase chain reaction (PCR) was used for the detection and quantification of ARGs, and denaturing gradient gel electrophoresis (DGGE) was used for molecular fingerprinting of the eubacterial community.

\section{Mass Spectrometry}

Reliable quantification of chemical compounds can be performed with high sensitivity with mass spectrometry (MS). Sample preparation (e.g. sample cleanup and analyte isolation) is necessary prior to MS and there are many techniques and variants of these available. To review them all is however, outside the scoop of this thesis. Instead, one possible combination of techniques is presented here; sample cleanup with solid-phase extraction (SPE), analyte separation with liquid chromatography (LC) and finally detection and quantification with MS.

\section{Principles of mass spectrometry and accompanying preparatory methods}

In preparation for analysis in MS, it is first necessary to concentrate the analyte and remove unwanted compounds from the sample. This can be done with SPE. SPE is performed in a column of glass or plastic which consists of adsorbents chosen to have high affinity for the analyte of interest. The column is first conditioned, i.e. the adsorbents are made to be adhesively accessible to the analytes by washing them with methanol. Next, the sample is applied to the column, which causes the analytes to adsorb to the column. Unwanted compounds with low affinity for the adsorbents pass through the column. Finally, the analytes are eluted from the column with a solvent which can be used with the mobile phase in the LC (Devanshu et al., 2010).

After SPE, the analyte of interest is further separated from unwanted compounds in the LC. In the LC, a mobile phase (i.e. a liquid) containing the eluate from the SPE is passed through a column which contain a solid phase. The conditions in the LC column are set up to enable different compounds in the mobile phase to travel through the solid phase at different speeds. This separates the different compounds in a time-dependent manner, and enables the analyte of interest to be further isolated prior to detection in the MS (Ardley, 2003). 
The separated analyte in the mobile phase continues from the LC to a part of the MS known as an ion source, the purpose of which is to ionise the analyte. Ions can be created by a technique known as electrospray ionisation (ESI). This involves the mobile phase with the analyte passing through an electrically charged tube or capillary which lead to the ion source chamber. As the mobile phase emerges from the tip of the tube, it will turn into an electrically charged aerosol. As the charged droplets continue to travel through the ion source chamber the solvent part of the mobile phase is gradually evaporated. Evaporation is performed either by shearing the droplets with a nebulising gas, or by having an increased temperature in the ion source chamber. Either way, as the droplets get smaller the charge density will eventually increase to a point where the charge is transferred to the analyte in the droplets, effectively creating ionised analyte in gas phase. These ions then continue into the mass analyser (Ho et al., 2003; Niessen, 2003).

There are many different mass analysers, a common one being the triple quadropole-mass spectrometer (MS/MS) also known as the tandem mass spectrometer. A MS/MS consists of three parts in sequence (Kushnir et al., 2011). The first part consists of four parallel metal rods, were each pair of rods opposite of one another have a similar electrical field applied over them. On one pair, a DC current is applied, and on the other pair, an AC current is applied. When an ion travels between these rods, its movement while be affected by the oscillations of the AC current depending on the ions mass to charge ratio $(\mathrm{m} / \mathrm{z})$. The AC current is set to affect ions of a particular $m / z$ so that ions which have a different $m / z$. than the desired analyte will be affected by the electrical field in such a way so that they collide with the metal rods and are neutralised. Meanwhile, only ions with an $m / z$ such as the desired analyte will be able to travel to the electrical field and reach the next part of the mass analyser. The next part of the MS/MS is a collision cell where the ions are fragmented by collision with a neutral gas (Ho et al., 2003). A particular ion species always fragments in the same characteristic way which enables the MS/MS to separate analytes on two parameters, namely $\mathrm{m} / \mathrm{z}$ and fragmentation patterns (Kushnir et al., 2011). The ion fragments continue into the third part of the mass analyser which functions exactly as the first, that is, ions are separated in an electrical field depending on their $m / z$. In this case of course, there is not only one ion species, but several different fragments (Ho et al., 2011). Regardless, after separation in the third part of the mass analyser, the ions enter a detector where they are finally detected and quantified. MS/MS allows for the data acquisition to be carried out in a mode called multiple reaction monitoring (MRM), so called since it monitors not only the parent ion of the analyte, but also the fragments of the ion. This increases specificity and sensitivity (Kushnir et al., 2011). 


\section{Applications of LC-MS}

The high sensitivity, specificity and dynamic range of LC-MS methodology have prompted its use in many different applications. Its clinical applications include screening for inborn errors of metabolism and identification of haemoglobin variants (Ho et al., 2003). It has also shown its use for quantification of complex chemical compounds from environmental matrices at numerous occasions, determination of antibiotics in water environments being one example (Kolpin et al., 2002; Abuin et al., 2006; Pei et al., 2006; Segura et al., 2009).

\section{Real-time PCR}

\section{The polymerase chain reaction}

PCR is an essential biotechnological method which was developed by Kary Mullis in the 80s (Mullis et al., 1987). PCR allows the amplification of small amounts of DNA, enabling the use of downstream applications which require high quantities of DNA. Essential to the amplification reaction are DNA primers which are complementary to conserved parts upstream and downstream of the desired DNA amplicon. The primers, and the DNA to be amplified, are put together in a buffered solution suitable for DNA amplification and subsequently put into a thermal cycler which raises the temperature swiftly. As the temperature gets high enough, the double-strands of the DNA melts and becomes single-stranded. After the melting, the temperature is lowered, allowing the primers to anneal to the complementary parts of the single-stranded target DNA. Finally, the temperature is raised further to optimise the conditions for DNA polymerisation. The polymerisation is catalysed by a DNA polymerase (traditionally Taq polymerase) which essentially doubles the amount of the target amplicon. Cleverly, the DNA polymerases used in PCR are heat-stable which means they are not destroyed when subjected to the high temperatures used to melt the DNA. This makes it possible to repeat the three steps of DNA denaturation, primer annealing and DNA extension, enabling an effective doubling of the amount of target DNA every cycle (Kubista et al., 2006).

PCR is useful in many applications including gene detection and routine diagnostics. However, although the amplification is exponential at the beginning, eventually the substrates will be used up and the amplification will reach a plateau-phase were further accumulation of product cannot continue. Furthermore, PCR inhibitors which may be in the sample and poorly optimised protocols will limit the efficiency of the reactions meaning the amplification per cycle will not be a perfect doubling. These factors taken together means that it is difficult and unreliable to try to calculate the starting concentration 
of target DNA from the quantity of end products in a PCR (Ginzinger, 2002).

\section{PCR monitoring in real-time}

Real-time PCR is a PCR-based method which was invented in 1996, which addresses the problems of quantification with PCR. It combines fluorescent techniques with PCR, usually in such a way so that generation of PCR product corresponds to an increase in fluorescence. By monitoring the fluorescence in real-time, the increase in fluorescence can be known for each cycle. By comparing the fluorescence with the fluorescence from standard reactions with known numbers of starting templates, both the efficiency of the reaction, and the starting number of target DNA copies can be inferred (Wilhelm et al., 2003).

\section{Detection formats used in real-time PCR}

Despite the fact that most real-time PCRs use fluorescence as a means of measurement, many conceptually different ways of generating the fluorescence exist (Wilhelm et al., 2003). Three of these will be discussed here.

SYBR Green is a fluorophore which intercalates with double-stranded DNA. When in solution, it does essentially not have any fluorescence. However, when bound to DNA, it exhibits an intense fluorescence. By having an abundance of SYBR Green molecules in a PCR, SYBR Green will intercalate and fluoresce proportionally to the amount of double-stranded DNA generated when excited. By measuring the fluorescence each cycle, the increase in PCR product can thus be monitored. While SYBR Green is a very common real-time PCR detection format, it does have its drawbacks. Particularly, as SYBR Green binds indiscriminately with any double-stranded DNA, binding to spurious products such as primer-dimers or unspecific DNA species will contribute to the fluorescence signal. This problem can be alleviated by competently optimising the PCR assay (Kubista et al, 2006).

In TaqMan assays, a probe is used in addition to the usual primer pair in the PCR reaction. A TaqMan probe is a DNA oligonucleotide complementary to a conserved portion of the target DNA in between regions which the usual primers are complementary to. Differently than the regular primers, TaqMan probes have a reporter fluorophor attached to the 5'-end, and a quencher molecule attached on the other side. The close proximity of the fluorophor to the quencher makes it impossible for the probe to fluoresce. However, after binding to the template DNA, the fluorophor and quencher are endonucleolytically cut away from the 
probe by the DNA polymerase. When the fluorophor is set free from the close proximity of the quencher, it can fluoresce. For each cycle in the PCR, the amount of free fluorophor will increase in the reaction solution proportionally to the amount of target DNA generated (Wilhelm et al., 2003). The benefits of TaqMan assays include the fact the probe adds another level of specificity to the reaction, lowering the risk of unspecific amplification. Spurious products such as primer-dimers do not contribute to the fluorescence signal either. On the other hand, melting curve analysis cannot be used with TaqMan assays as the probes cannot be regenerated. Assays will also still need to be optimised, as low efficiency and primer-dimer formation will still lower the overall performance of the assay (Wilhelm, et al., 2003).

Light-Upon-eXtension (LUX) is another detection format in which one of the primers is modified. A fluorophor is attached close to the 3 '-end of a primer which is designed with a part non-complementary to the target DNA, but complementary to itself. This makes the primer go into a hair-pin loop conformation which quenches the fluorophor. When the primer is incorporated into DNA template at elongation, the hair-pin loop is broken and the fluorophor is allowed to fluoresce. The fluorescence is thus proportional to the amount of PCR product. The benefits of a LUX-system are having a high specificity while not needing a probe and the possibility of using melting curve analysis. Furthermore, the hair-pin loop structure has the possibility of alleviating some of the problems with primer-dimer formation in the reaction (Nazarenko et al., 2002).

\section{Quantification with real-time PCR}

Quantification in real-time PCR is performed by first selecting an arbitrary threshold value for the fluorescence signal. The cycle at which the signal reaches the threshold is called the quantification cycle $\left(C_{\mathrm{q}}\right)$. The threshold should be chosen so that the fluorescence signal is strong enough to be distinctly discernible from the background fluorescence (i.e. the $C_{\mathrm{q}}$ should be in the exponential phase of the PCR amplification) in all samples. It is also important not to choose the threshold so that the $C_{\mathrm{q}}$ lies in the plateau-phase of the PCR amplification, where the amplification behaviour of the PCR is indeterminable.

As the fluorescence in an unknown sample reaches the $C_{\mathrm{q}}$, the starting amount of DNA template can be inferred by the following logic. Let $N_{0}$ be the starting amount of DNA template, $S$ the fluorescence signal, $p$ the proportionality constant which relates the relation between the fluorescence signal and the number of DNA templates, and $E$ the efficiency of the reaction (which will be a value between 0 and 1). The expression for $S$ can then be written thus 


$$
S=p N_{0}(1+E)^{C_{q}}
$$

Solving for $C_{\mathrm{q}}$ yields the expression

$$
C_{q}=-\frac{\log N_{0}}{\log (1+E)}+\frac{\log (S / p)}{\log (1+E)}
$$

If the formula is simplified by defining

$$
k=-\frac{1}{\log (1+E)}
$$

and

$$
m=\frac{\log (S / p)}{\log (1+E)}
$$

the expression for $C_{\mathrm{q}}$ becomes

$$
C_{q}=k \log N_{0}+m
$$

It is easy to see from this expression that $C_{\mathrm{q}}$ is linear to $\log \left(N_{0}\right)$ with the slope $k$ and the intersect $m$. By using standards of known template concentrations, $k$ and $m$ can be determined by regression analysis. By solving for $N_{0}$

$$
N_{0}=10^{\left(C_{q}-m\right) / k}
$$

$N_{0}$ can be inferred in unknown samples from the $C_{\mathrm{q}}$-values acquired in the real-time PCR.

Further information can be gleaned from the function of the standard curve. The intersect, it is realised, occurs when $N_{0}=1$. This means that the intersect corresponds to the theoretical $C_{\mathrm{q}}$ of a reaction containing one starting molecule of target DNA. Furthermore, solving for $E$ from the slope $k$ gives an expression for the efficiency

$$
E=10^{-\frac{1}{k}}-1
$$

which apparently can be calculated directly if the inclination of the standard curve is known. Inversely, by realising that the maximum value of $E$ is 1 (which corresponds to a doubling every cycle), it is easy to calculate that an efficiency of $100 \%$ is achieved when the standard curve has an inclination of about -3.32 . 
Since the quantification is dependent on the known quantities of starting template in the standards, the accuracy of the real-time PCR reaction is dependent on the accuracy of the techniques used for quantifying the standards (Wilhelm et al., 2003). However, new up and coming PCR techniques dubbed digital PCR circumvents the problems of quantification by standard. In these methods, reactions are absolutely measured and the number of gene copies in the original sample is calculated statistically from a Poisson distribution (Hindson et al., 2011).

\section{Applications of real-time PCR}

Real-time PCR has a dynamic range of over eight orders of magnitude, and can in theory detect a single gene copy in a sample. Since it is also a robust and reliably reproducible technique, real-time PCR has become a widely used method (Ginzinger et al., 2002; Wilhelm et al., 2003), with uses including routine diagnostics (Maurin, 2012). Its reliability and high sensitivity also makes real-time PCR ideally suitable for gene quantification in environmental samples, where the DNA amounts are usually low and inhibitors abundant. Environments in which real-time PCR have been successfully been applied on include river sediment (Pei et al., 2006), soil (Knapp et al., 2010), wastewater and activated sludge (Auerbach et al., 2007).

\section{Denaturing gradient gel electrophoresis}

\section{The principles of denaturing gradient gel electrophoresis}

Denaturing gradient gel electrophoresis (DGGE) is a melting gel technique developed for detection of mutations. It is a common tool for genetic studies of diseases, for instance by detection of single nucleotide polymorphisms (SNPs), and has proven to be a sensitive and reproducible method (Bjørheim et al., 2002).

The basis of DGGE is the property of DNA molecules to become single-stranded, to melt, at the appropriate temperature or at a particular concentration of a chemical denaturing reagent (Fig. 9). Depending on the length of the DNA and the nucleotide sequence, different DNA molecules will melt at different conditions. If the DNA is longer than 300-500 bp, parts of the DNA molecule which are more susceptible to melting will melt at denaturing conditions less severe than other parts. As such, a long DNA molecule can be divided into discrete melting domains, with the part sensitive to denaturation being called the low melting domain. In a DGGE, these properties are exploited by letting DNA be electrophoresed through a polyacrylamide gel which contains a linearly increasing gradient 
of chemical denaturants (such as urea and formamide). The polyacrylamide gel itself is kept in a heated bath to further increase the denaturing conditions. As the DNA travel from a low denaturing environment to a high, eventually the low melting domain of the DNA will encounter a condition at which it melts. As the DNA molecule becomes partially single-stranded, the single-stranded breaks will protrude from the main body of the DNA helix. This sterically hinders the DNA molecule when it traverses the pores in the polyacrylamide gel. In effect, it means that unmelted DNA will travel faster through the gel, whereas a DNA molecule with a melted domain will be severely slowed at the location at which the particular denaturing conditions melted the domain. Finally, the DNA molecules in the gel are visualised as bands with intercalating fluorophors (Abrams et al., 1992; Bjørheim et al., 2002).

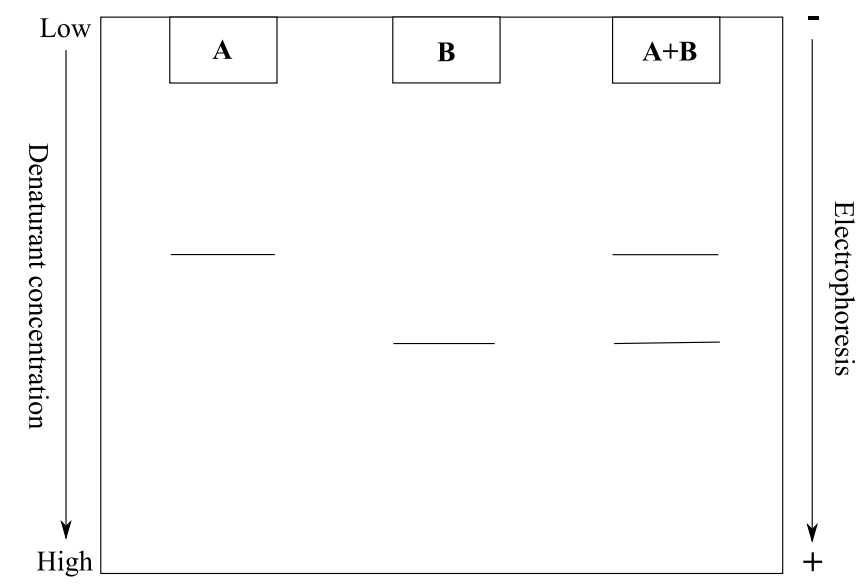

Figure 9. A schematic of a DGGE gel. In the schematic, a DNA species with low melting temperature (A) and a DNA species with high melting temperature (B) are loaded onto the gel. Both A and B travel down through the gel by electrophoresis. The concentration of denaturants increases linearly from top to bottom and $\mathrm{A}$ will melt higher up in the gel than $\mathrm{B}$, meaning that $\mathrm{A}$ will be stopped higher up in the gel than $\mathrm{B}$. If a mixed sample $(\mathrm{A}+\mathrm{B})$ is loaded onto and electrophoresed through the gel, A and B will be separated.

DGGE is usually performed on PCR products since DGGE requires a fair amount of DNA. To prevent getting fully melted (i.e. completely single-stranded DNA) in the DGGE, and to ensure that the melting domain which separates the DNA species is not the highest melting domain, a PCR primer can be modified with a non-complementary GC-rich region. A succession of guanines and cytosines will dramatically raise the melting temperature of that particular domain of the DNA molecule, ensuring that the DNA will not melt completely in the DGGE (Abrams et al., 1992). 


\section{Applications of DGGE}

Taking advantage of the melting properties of DNA, it is possible to separate DNA molecules which only differ in as little as a single nucleotide. Detection of mutations and SNPs (Bjørheim et al., 2002) are therefore common applications for DGGE. For studies of whole microbial communities, it is common to use differences in the 16S rRNA gene to separate different bacterial taxa in the same sample (Fromin et al., 2002). The PCR primers are then designed to be complementary to conserved parts of the gene, with the amplicon region being over a variable part. Each unique band will then correspond to a bacterial taxon. A sample will then have a particular band pattern depending on which bacteria was in it (Muyzer et al., 1993). This molecular fingerprint can then be compared to fingerprints from other samples. It is also possible to assess the diversity and evenness of bacterial taxa using this method. Since PCR is a competitive reaction, DNA from more abundant taxa will end up being more abundant as PCR products as well. The band intensity will therefore correlate to how abundant the taxa are in the samples. By viewing the number of bands as the number of species, and the band intensity as the abundance of that particular species, diversity indices (e.g. Shannon diversity) and corresponding evenness can be calculated (Fromin et al., 2002; Gafan et al., 2005).

Studies using 16S rRNA-based DGGE have been performed on samples from many different environments, including constructed wetlands (CWs) (Ibekwe et al., 2007), activated sludge (Boon et al., 2002) and high temperature petroleum reservoirs (Wang et al., 2008). DGGE can also be used on functional genes when the interest is a particular metabolic process, for example ammonium oxidation (Verhamme et al., 2011) and denitrification (Sundberg et al., 2007). 


\section{Aims}

Antibiotic resistance is a major global threat which must be addressed. Recently, the environment has been highlighted as an important factor in development and dissemination of antibiotic resistance genes by horizontal gene transfer. It has also been suggested that low, subinhibitory concentrations of antibiotics may select for antibiotic resistance genes in environmental bacteria. The aim of this thesis was to elucidate the effects of anthropogenic antibiotic contamination on natural bacterial communities from aquatic environments, particularly regarding how levels of antibiotic resistance genes are affected. The effect on class 1 integrons was also assessed, as they are important agents of horizontal gene transfer and are likely important in the dissemination of antibiotic resistance genes. To determine the role of human perturbation in the dissemination of antibiotic resistance genes, environments where low concentrations of antibiotics (i.e. concentrations commonly encountered in wastewater) are prevalent and environments which are anthropogenically impacted with high levels of antibiotics were investigated. The specific aims of the papers herein were:

Papers I-II To assess the levels of antibiotics, antibiotic resistance genes and class 1 integrons in different anthropogenically impacted and undisturbed aquatic environments to determine if human activities can be linked with increases in antibiotic resistance gene and class 1 integron concentrations.

Paper III To investigate the efficiency of constructed wetlands in removing antibiotics from water and the potential effects of low, environmentally relevant concentrations of antibiotic contamination on antibiotic resistance gene and class 1 integron concentrations.

Paper IV To investigate the effect of low, environmentally relevant concentrations of antibiotics on prevalence and development of antibiotic resistance genes and class 1 integrons in a highly controlled environment, i.e. microcosms consisting of water and sediment from an environmental source only slightly affected by human activities. 


\section{Antibiotics and resistance genes in water environments affected by human activities (Papers I \& II)}

The correlations between antibiotic prevalence and prevalence of antibiotic resistance genes (ARGs) and class 1 integrons in urban aquatic environments were assessed in Papers I-II. In Paper I, water and sediment samples were collected from 19 different sites in the vicinity of the Pakistani city of Lahore (population: >10,000,000). The sampling sites (Fig. 10) included rivers (R1-R10), a dam (D), a canal (C1, C2), a sewage drain in the proximity of three hospitals (SD) and near drug formulation facilities (P1a, P1b, P2-P4). The level of anthropogenic disturbances of the sampling sites ranged from close to pristine to heavily influenced by human waste. Antibiotic concentrations of 22 different antibiotics were measured in the water phase with mass spectrometry (MS) and 5 ARGs (sull, ermB, dfrAl, tetA and tetB) and intII were measured in the sediments (Table 1). In Paper II, water and sediment were sampled from the Swedish river Stångån over three months during the winter season. Samples were taken upstream and downstream of a wastewater treatment plant (WWTP) which discharges treated effluent in the adjacent river. The WWTP receives urban waste from the city of Linköping (population: $<150,000$ ). The water phase was analysed for 10 different antibiotic compounds. The sediment samples were analysed for 7 ARGs (sull, ermB, dfrAl, tetA, tetB, qnrS and vanB) and intIl (Table 1).

Real-time polymerase chain reaction (PCR) was used for gene quantification in both Papers I and II. The sediments analysed were from complex environments and the ability to quantify low abundances of genes was desired. As such, real-time PCR was ideal both with its high sensitivity and specificity. There are however, shortcomings with this methodology when it comes to using it in assessing the general resistance prevalence in the bacterial community of an environment. Only a limited number of ARGs can be analysed and even if these are not detected, indigenous bacteria may harbour other ARGs which confer resistance. The selection bias inherent in this methodology is however preferable to the traditional direct approach of cultivating resistant bacteria from the environment. Since more than $99 \%$ of all environmental bacteria are uncultivable (Lewis, 2009), this introduces a far greater bias. However, using quantitative real-time PCR does require care when selecting which ARGs to analyse. In Papers I and II, the analysed ARGs were chosen to encompass environmentally common genes conferring resistance to some of the most common antibiotic classes. It is also notable that by quantifying ARGs, the genes which are quantified are not necessarily residing within bacteria, but may be quantified while in free form in the environment. In other words, an extracellular ARG quantified does not equal a concurrent resistance phenotype. Mao et al., 2014, estimated that the fraction of 
extracellular DNA exceeded the fraction of intracellular DNA in river sediments. While this means that ARG quantification overestimates the actual gene-carrying bacteria in a sample, as an indicator of environmental impact and possibility of further dissemination of ARGs, it may be a superior indicator compared to a true measure of the number of resistant bacteria. Extracellular ARGs can be transferred to bacteria by horizontal gene transfer (HGT), and stresses such as exposure to antibiotics have been demonstrated to increase transformation rates in some bacteria (Prudhomme et al., 2006). Furthermore, extracellular DNA can be stabilised by adhesion to sediment particles and proximity to bacterial biofilms, which may further increase likelihood of uptake (Davison, 1999).

Table 1. ARGs and the integrase gene on class 1 integrons, intIl, were analysed throughout Papers I-IV. 'Resistance phenotype' denotes the classes of antibiotics to which the gene product confers resistance to.

\begin{tabular}{lll}
\hline Gene & Gene product & Resistance phenotype \\
\hline dfrA1 & Dihydrofolate reductase & Trimethoprims \\
ermB & rRNA methylase & Macrolides / Lincosamides \\
int/1 & Integrase & - \\
qnrS & Topoisomerase-binding protein & Quinolones \\
sull & Dihydropteroate synthase & Sulphonamides \\
tetA & Energy-dependent efflux protein & Tetracyclines \\
tetB & Energy-dependent efflux protein & Tetracyclines \\
vanB & D-Alanine-D-Lactate ligase & Glycopeptides \\
& & \\
\hline
\end{tabular}

Antibiotic concentrations at the sampling sites in Pakistan in Paper I were found to be mostly in the low $\mathrm{ng} \times \mathrm{L}^{-1}$ range in sites not impacted by human activities. These sites included all river sites outside of Lahore (R4-R10) and the dam (D). However, anthropogenically impacted sites showed much higher concentrations of antibiotics. These sites included the sewage drain close to three hospitals (SD), near the drug formulation facilities (P1a, P1b, P2-P4) and the river sites in and after Lahore (R2, R3). Lincosamide, oxytetracycline, sulfamethoxazole and trimethoprim were found in concentrations above $1,000 \mathrm{ng} \times \mathrm{L}^{-1}$ in the sewage drain, about 10-10,000 times higher than in the unperturbed sites. The sites near the drug formulation facilities had by far the highest concentrations of antibiotics. Oxytetracycline, trimethoprim and sulfamethoxazole were measured at 27,000, 28,000 and 49,000 $\mathrm{ng} \times \mathrm{L}^{-1}$ respectively in the site with the highest concentrations of antibiotics (P4). These concentrations are about one to two orders of magnitude lower than minimum inhibitory concentrations (MICs) for reference strains (Andrews, 2001). Antibiotic concentrations were also shown to be higher in the river Ravi downstream of Lahore (R3) than compared to upstream (R1). The same trend was observed in Paper II. Antibiotic concentrations were found to be higher in Stångån River downstream of a 
WWTP than upstream, even though the concentrations were generally lower compared to the concentrations in river Ravi. In Stångån, antibiotics were below the limit of quantification upstream of the WWTP, whereas clarithromycin, clindamycin and trimethoprim could be found in low $\mathrm{ng} \times \mathrm{L}^{-1}$ concentrations at the downstream sites.

In both Papers I-II, higher antibiotic concentrations correlated to higher ARG and integron concentrations for most sites. ARG and intIl concentrations (Fig. 11) were higher in river Ravi downstream of Lahore (R3) than upstream (R1). sulI was measured to 730 genes $\times$ $10^{6} 16 \mathrm{~S}$ rDNA copies ${ }^{-1}$ at the upstream site (R1) and increased to 140,000 genes $\times 10^{6}$ $16 \mathrm{~S}$ rDNA copies ${ }^{-1}$ downstream of Lahore (R3). intIl concentrations were measured at 15,000 genes $\times 10^{6} 16 \mathrm{~S}$ rDNA copies ${ }^{-1}$ at the upstream site $(\mathrm{R} 1)$ and at 770,000 genes $\times 10^{6}$ $16 \mathrm{~S}$ rDNA copies ${ }^{-1}$ at the downstream site (R3). In Stångån too, ARG and intIl concentrations increased downstream of the WWTP. Of particular note were the concentrations of sulI, ermB and tetA which showed a particularly high increase from the upstream to the downstream sites. For sulI, this corresponded to a mean increase of 220 to 11,000 genes $\times 10^{6} 16 \mathrm{~S}$ rDNA copies ${ }^{-1}$. ermB and tet $A$ had mean increases from 670 to 5,300 genes $\times 10^{6} 16 \mathrm{~S}$ rDNA copies ${ }^{-1}$ and 3.3 to 150 genes $\times 10^{6} 16 \mathrm{~S}$ rDNA copies ${ }^{-1}$ respectively. For all ARGs analysed except sulI, concentrations were actually higher in the upstream site in Stångån than the upstream site in Ravi (only sulI could be quantified at this sampling point). In the downstream sites, sulI, dfrAl and tetA were found in higher concentrations in Ravi than in Stångån. All other analysed ARGs were found at similar concentrations. Pei et al., 2006, also observed an increase in sulI concentrations in an American river, from pristine upstream locations to anhtropogenically affected downstream locations. sulI levels were measured to progressively increase from around $10^{0}$ to $10^{2}$ genes $\times 10^{6} 16 \mathrm{~S}$ rDNA copies ${ }^{-1}$, which was lower than the levels observed in Papers I-II. The other measured ARGs (sulII, tet $O$ and tet $W$ ) were also observed to increase in abundance from the pristine site to the anthropogenically impacted sites. Similar to Paper II, in Marti et al., 2013, ARG concentrations in a river were analysed upstream and downstream of a WWTP in Spain. While ARG levels in biofilms were observed to be slightly elevated downstream, the concentrations of ARGs in the sediment phase were observed to be about the same upstream and downstream. For sulI, this concentration was approximately 5,000 genes $\times 10^{6} 16 \mathrm{~S}$ rDNA copies $^{-1}$, which is comparable to the concentrations observed in Paper II, but lower than the concentrations which were measured in the downstream river site R3 in Paper I.

Comparing the upstream and downstream river sites in Paper I and Paper II is interesting since both systems are similar (i.e. fairly undisturbed river which passes and receives waste from a city) although located in greatly different locations. The amount of waste generated by a city the size of Lahore is of course also different than compared to Linköping. However, the unaffected upstream sites showed similar profiles in ARG and integron 


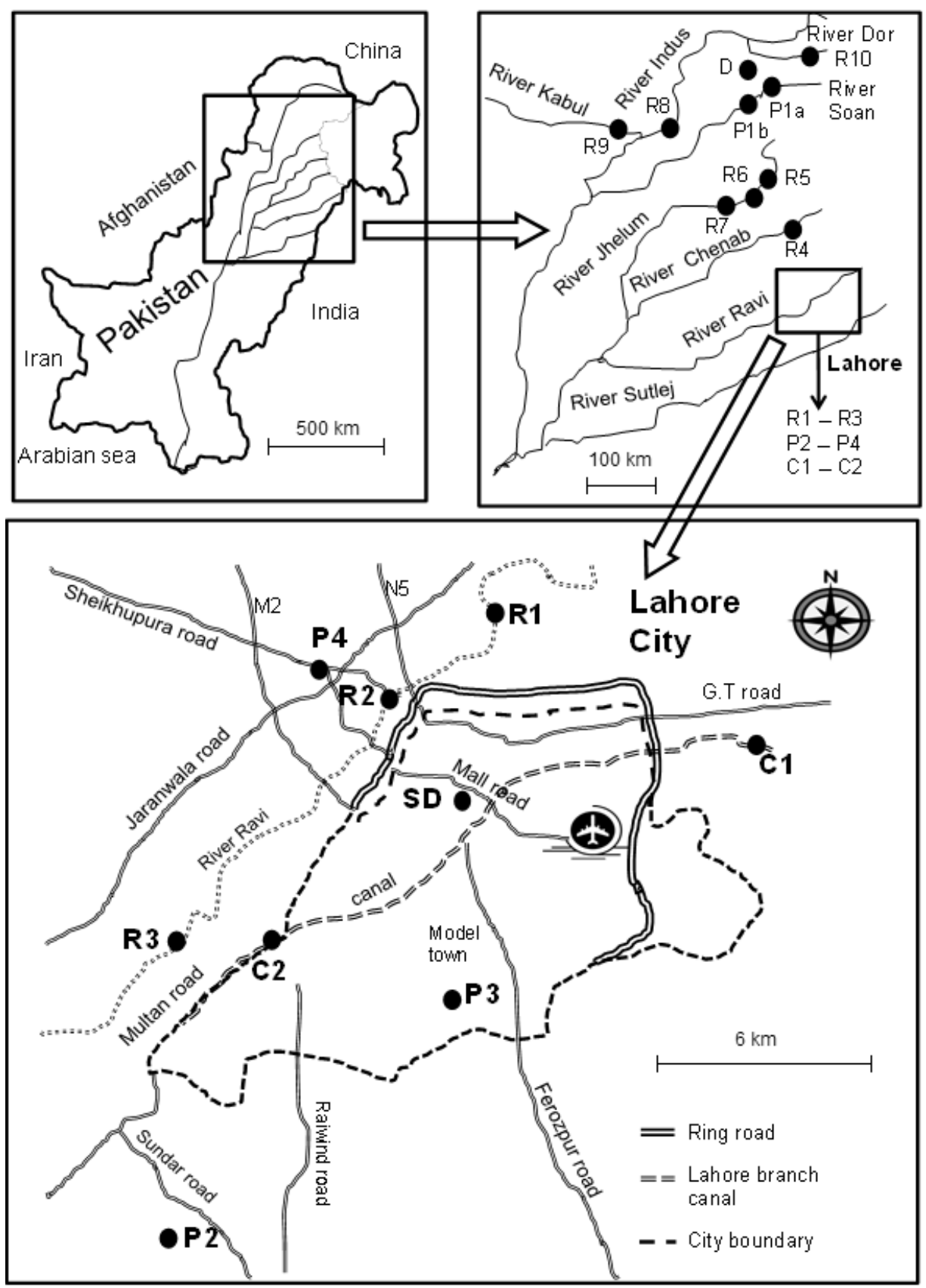

Figure 10. Map of a region in the vicinity of Lahore, Pakistan. Sampling sites are highlighted in bold. Image modified from Khan et al., 2013. 
content (with the exception of $e r m B$ concentrations). The trends of increasing ARGs and integrons after the river passed the city (or in Paper II; downstream the point where wastewater was discharged) were the same for both systems, showing that waste generated from the urban milieu acts as a point source of ARG and integron contamination. It should be noted that the concentrations of antibiotics measured in both river systems are not necessarily high enough to cause a selection for antibiotic resistance. It may be that the increase in ARGs is simply due to accumulation of ARGs from different point sources in the urban environment themselves.

In Paper I, the site which had the highest concentrations of antibiotics, near the drug formulation facility at Shahdara Industrial Estate (P4), also had the highest concentrations of ARGs and integrons (intIl was measured at 6,900,000 genes $\times 10^{6} 16 \mathrm{~S} \mathrm{rDNA}$ copies $^{-1}$ ). sulI and $d f r A l$ where found at particularly high concentrations; 800,000 genes and 430,000 genes $\times 10^{6} 16 \mathrm{~S}$ rDNA copies ${ }^{-1}$ respectively. This is noteworthy, since antibiotics to which they confer resistance (sulfamethoxazole and trimethoprim) were also found at very high concentrations at this site. The concentrations of these antibiotics were likely high enough to adversely affect indigenous bacteria, which suggests that the corresponding high concentrations of ARGs are a result of selection. Other studies too have observed elevated ARG abundances and MICs at sites with extremely high levels of antibiotic contamination. Effluent from a WWTP in India, receiving waste from drug manufacturing facilities, was shown to contain ciprofloxacin at $31,000,000 \mathrm{ng} \times \mathrm{L}^{-1}$ with accompanying increases in ARG and class 1 integron abundances in the river downstream of the wastewater discharge point (Larsson et al., 2007; Kristiansson et al., 2011). In Li et al., 2010, increased MICs for oxytetracycline and a variety of tet genes were measured for bacteria in a river downstream a WWTP connected to a drug manufacturing facility. The oxytetracycline concentrations in the river were measured to $640,000 \mathrm{ng} \times \mathrm{L}^{-1}$. It is unlikely that such high levels of antibiotic contamination are necessary for proliferation of ARGs however. The antibiotic concentrations measured at P4 in Paper I are low in comparison to these other studies, yet the high levels of ARGs indicate that they are selected for. Tetracycline resistance genes tet $A$ and $t e t B$ were found at $\mathrm{P} 4$ at comparatively low concentrations $(8,400$ genes and $7.0 \times$ $10^{6} 16 \mathrm{~S}$ rDNA copies ${ }^{-1}$ respectively) despite the high concentrations of oxytetracycline observed at this site. The $t e t B$ concentrations near the drug formulation facility at Shahdara Industrial Estate (P4) were actually comparable to the downstream sites in river Ravi (5.0 genes $\times 10^{6} 16 \mathrm{~S}$ rDNA copies $\left.{ }^{-1}\right)$ and Stångån $\left(2.0\right.$ genes $\times 10^{6} 16 \mathrm{~S}$ rDNA copies $\left.{ }^{-1}\right)$. It is, however, likely that the indigenous bacteria in site $\mathrm{P} 4$ are conferred tetracycline resistance by some other tetracycline resistance gene. The extremely high concentration of class 1 integrons at this site may also suggest that integrons are important agents in the selection for ARGs at this site. 


\section{Removal and effect of low levels of antibiotics on surface-flow constructed wetlands (Paper III)}

As shown in Papers I-II, increases in ARG and integron prevalence are correlated to anthropogenic perturbation (e.g. discharge of wastewater effluent) and antibiotic concentration (at least for exceedingly high concentrations). This could potentially be a problem, as antibiotics are ubiquitous in urban waste. It is possible that wastewater-like concentrations of antibiotics exert a selective pressure on bacteria in the wastewater process, selecting for ARGs and thus making the wastewater treatment system into a hotspot for antibiotic resistance development and dissemination. In Paper III, it was investigated if constructed wetlands (CWs) can be used to efficiently remove antibiotics of concentrations commonly found in wastewater from water without causing a proliferation of ARGs and integrons. 8 surface-flow CWs in an experimental wetland park near Halmstad, Sweden, which had not previously been exposed to antibiotics, were used in the experimental set-up (Fig. 12). A mixture of 12 commonly used antibiotics were continuously added to 4 of the wetlands for 25 days, whereas 4 wetlands were used as controls. The concentrations of the antibiotics were selected so as to equal about 10 times the concentrations commonly encountered in wastewaters, which in turn were up to two to three orders of magnitude lower than MIC-levels for reference strains (Andrews, 2001). Water and sediment samples were taken over 100 days from the start of the experiment. Antibiotic concentrations were measured in the water phase using MS and 7 ARGs (sulI, ermB, dfrAl, tet $A$, tet $B, q n r S$ and $v a n B$ ) and intIl were measured in the sediment phase with real-time PCR (Table 1). Expression of ARGs and intIl was also measured by cDNA analysis. Furthermore, denaturing gradient gel electrophoresis (DGGE) was used to determine the diversity and evenness of the indigenous bacterial community.

The antibiotic measurements indicated that the removal efficiencies in the CWs were high. The highest average removal efficiencies were observed for erythromycin, oxytetracycline and tetracycline $(96 \%, 97 \%$ and $99 \%$ respectively). The lowest observed removal efficiency was $59 \%$ for clarithromycin. Azithromycin, ciprofloxacin, doxycycline and norfloxacin could not be detected, likely due to adsorption to sediment or soil particles. The antibiotic removal efficiencies observed were comparable to those of WWTPs. ARGs were detected and quantified (Fig. 11) in both control wetlands and the wetlands exposed to antibiotics. The ARGs which were most prevalent and in highest abundances were sulI (median concentration of 380 genes $\times 10^{6} 16 \mathrm{~S}$ rDNA copies ${ }^{-1}$ ) and tetA (median concentration of 8 genes $\times 10^{6} 16 \mathrm{~S}$ rDNA $\operatorname{copies}^{-1}$ ). tet $B$ was also found in most samples ( 48 out of 72 samples) but was below the limit of quantification in all but 5 samples. ermB, $d f r A l$ and $v a n B$ were also detected in a few samples, while qnrS could not be detected in any sample. The concentrations for most ARGs were comparable to the values measured in 


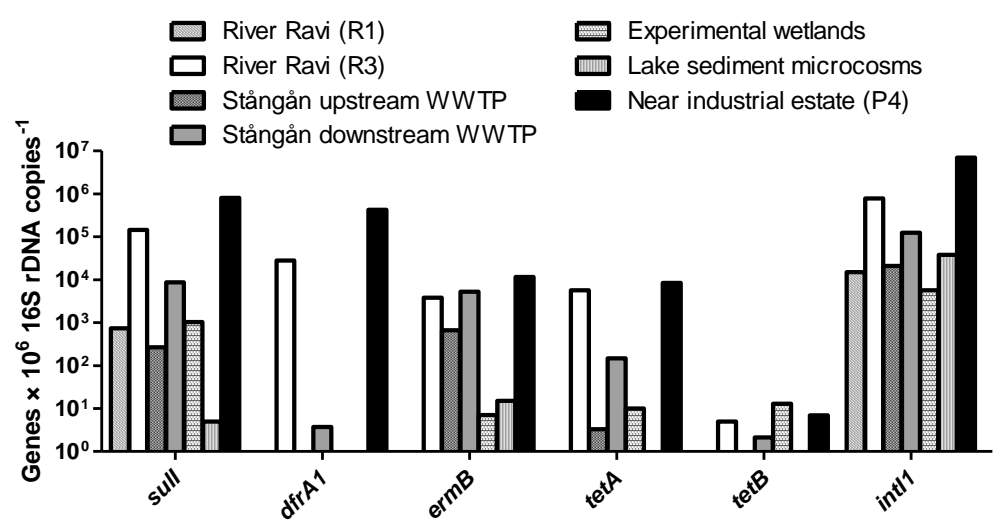

Figure 11. ARGs and intIl quantified in different sites in Papers I-IV. Values are presented as means of the quantifiable samples where applicable (i.e. where $n>1$ ).

Paper II at the sites in Stångån upstream of the WWTP. The exception was ermB which was found at higher concentrations in Stångån than in the wetlands. cDNA was detected for all ARGs (except $q n r S$ ), but at lower concentrations than the corresponding genes. sulI cDNA was found at the highest concentration (median concentration of 44 genes $\times 10^{6} 16 \mathrm{~S}$ rDNA copies ${ }^{-1}$ ), and was the only cDNA species found at high enough concentrations to be quantifiable. cDNA of all other ARGs were detected at concentrations below the limit of quantification, with the exception of $q n r S \mathrm{cDNA}$, which was not detected at all. ARGs and cDNA thereof were detected and quantified in both the control wetlands and the wetlands exposed to antibiotics. No increase in prevalence or abundance of either ARG DNA or cDNA could be discerned in the wetlands exposed to antibiotics as compared to the control wetlands, although the time at which the samples were taken was found to be a significant factor determining concentrations of sulI DNA and cDNA. Class 1 integrons were prevalent and abundant in all wetlands; the median concentration of intIl was determined to be 4,900 genes $\times 10^{6} 16 \mathrm{~S}$ rDNA copies ${ }^{-1}$. Integron concentrations were somewhat lower in the wetlands than compared to the upstream site in Ravi (R1) and Stångån (Paper I and Paper II respectively), although did reach similar levels in the samples with the highest concentrations (maximum value was measured to 15,000 genes $\times 10^{6} 16 \mathrm{~S}$ rDNA copies ${ }^{-1}$ ). cDNA of intIl was also prevalent, although found at lower concentrations than the gene itself (median concentration: 440 genes $\times 10^{6} 16 \mathrm{~S} \mathrm{rDNA}$ copies $^{-1}$ ). Time was determined to be a significant factor for both DNA and cDNA concentrations of intI1. However, antibiotic exposure did not appear to have a significant effect on either abundance or expression of intI1. Bacterial diversity and evenness were not observably affected by the addition of antibiotics at the concentrations used. 


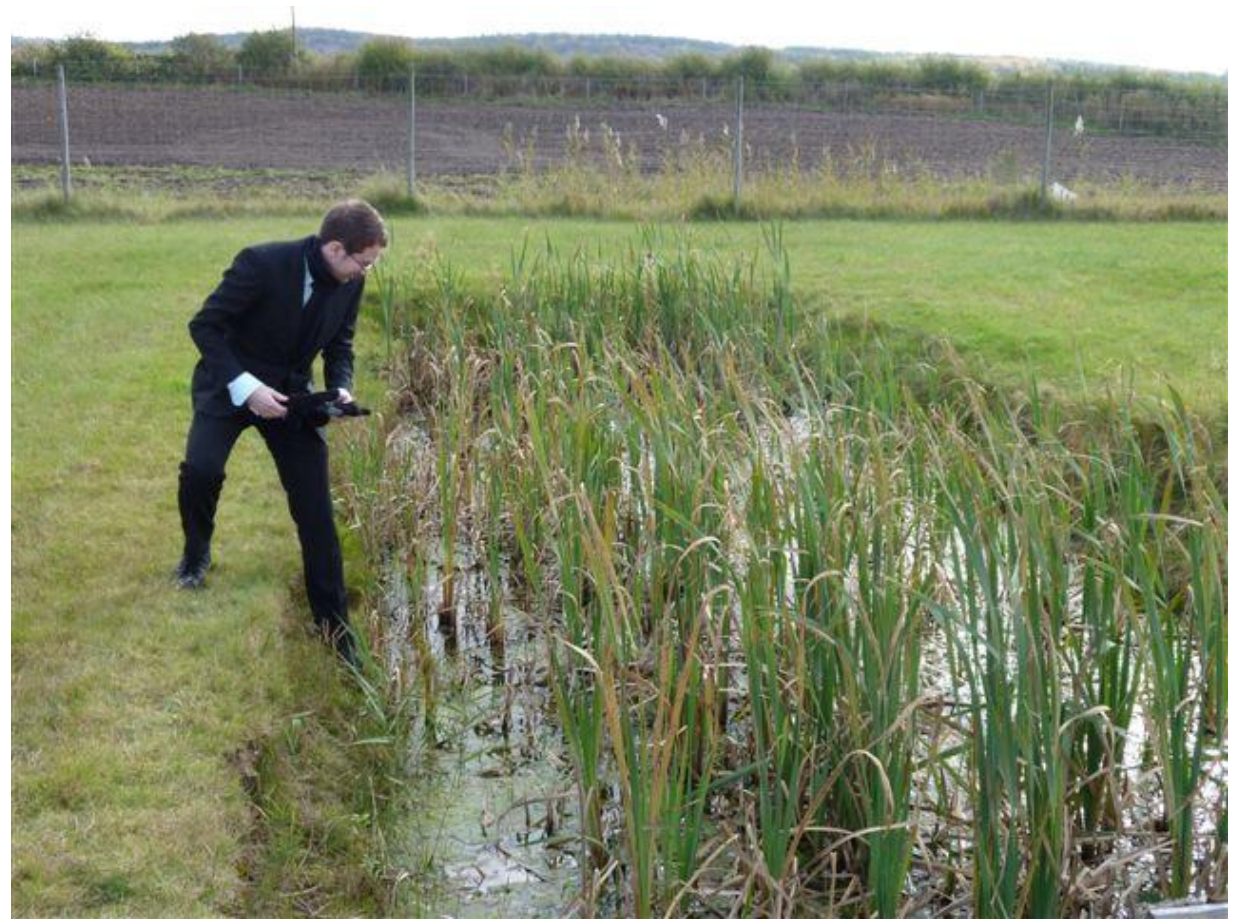

Figure 12. One of the experimental CWs used in Paper III. Photo by Per-Eric Lindgren.

The results suggest that the antibiotics at the concentrations used, did not select for ARGs. The cDNA analyses also suggested that the expression levels of ARGs were unchanged by the antibiotic exposure. Since only a selected number of ARGs were analysed, it cannot be ruled out that other ARGs (which were not analysed) did indeed proliferate and generate resistance in the indigenous bacteria during the antibiotic exposure. However, it would be expected that in such a case the antibiotics would have affected the bacterial community at large in the wetlands. No effect of the antibiotic exposure could be observed on bacterial diversity or evenness. The overall antibiotic removal efficiencies and the lack of effect on ARGs suggest that surface-flow CWs may be useful in treating wastewater containing these levels of antibiotics.

The antibiotic exposure also had no observable effect on abundance or expression of the intIl gene of class 1 integrons. In Papers I-II, an increase in intIl could be observed from unperturbed water environments to water environments exposed to human waste, at which the concentrations of antibiotics were similar to what was used in the wetlands in Paper III. Other studies have also indicated that abundances of class 1 integrons in aquatic environments are correlated to anthropogenic activities (Wright et al., 2008; Rosewarne et 
al., 2010; Gaze et al., 2011). However, all of these studies were on non-simulated systems exposed to a full spectrum of anthropogenic contamination. The exception was in Wright et al., 2008, were microcosms were also constructed from river water where intII abundances were shown to increase after addition of tetracycline and cadmium respectively. The concentrations of tetracycline used was, however, much higher $\left(30,000,000 \mathrm{ng} \times \mathrm{L}^{-1}\right)$ than compared to what was used in Paper III. ARGs too were seen to increase from unexposed to exposed environments in Papers I-II, even though this trend could not be reproduced in the wetland experiments in Paper III. A possible explanation is that the increase in ARGs and integrons arise from an accumulation from point sources in the urban milieu, which converges in the wastewater treatment system. Another possibility is that while low levels of relatively few antibiotics fail to affect a complex bacterial community, the huge diversity of different contaminants in (albeit in relatively low concentrations) anthropogenic waste, such as wastewater effluent, do have an effect. It should also be noted that in the experiment in Paper III, antibiotics were added in homogeneous concentration for only 25 days whereas a real aquatic environment exposed to human contaminants are likely to be exposed for a much longer time and with the possibility of concentrations of different contaminants differing significantly over time. 


\section{Effect of different levels of antibiotics on a lake sediment system previously unexposed to antibiotics (Paper IV)}

In Paper I it was shown that ARGs and integron concentrations increased significantly in a river as it passed the city of Lahore (and received waste from the city). Similarly, in Paper II, ARG and integron concentrations were observed to increase significantly downstream of a WWTP discharging treated wastewater received from the city Linköping. In Paper III on the other hand, no increase in ARG or integron concentrations could be observed when CWs were exposed to environmentally relevant concentrations of antibiotics. This prompts the question as to whether antibiotics of the low antibiotic concentrations commonly found in wastewater actually select for ARGs and integrons, or whether the increases observed in Papers I-II are due to some other factors. In Paper IV, a series of microcosms consisting of lake water and sediments gathered from the lake Nydalasjön, Sweden, were set-up. The lake is located near the city Umeå, but is not exposed to wastewater. The microcosms were exposed to a mixture of antibiotics, similar to which was used in Paper III. However, concentrations were varied between the microcosms. The concentrations used corresponded to $0,1,10$ and 1,000 times the concentrations commonly found in wastewater. The microcosms, which consisted of $200 \mathrm{~g}$ sediment and $300 \mathrm{~mL}$ lake water, were kept at $10^{\circ} \mathrm{C}$ and run for 100 days. Antibiotic concentrations were measured in the water and sediment phase with MS, and 7 ARGs (sull, ermB, dfrAl, tetA, tetB, qnrS and $v a n B$ ) and intIl were measured in the sediment phase with real-time PCR (Table 1).

Antibiotic quantification in the water phase of the microcosms showed that the concentrations adhered well to the theoretically calculated values. After 100 days the concentrations of most antibiotics had been reduced by close to $100 \%$. Only clarithromycin (70\% and $86 \%$ reduction in the $10 \mathrm{x}$ and $1000 \mathrm{x}$ microcosms respectively), erythromycin (73\% reduction in the $1 \mathrm{x}$ microcosm) and sulfamethoxazole $(74 \%$ reduction in the $1 \mathrm{x}$ microcosm) were reduced by less than $90 \%$. Only clarithromycin, clindamycin, trimethoprim and sulfamethoxazole were detectable in the sediment phase, and only in the 10x and 1000x microcosms. Sulfamethoxazole was only detectable at day ' 1 ' and day ' 7 ' in the 1000x microcosm. No antibiotics were detectable in any microcosm before addition of antibiotics or at any time in any of the control microcosms. ARGs were observed (Fig. 11) only sporadically and at low concentrations in the microcosm sediments. sull (detected in 16 out of 75 samples) and ermB (detected in 4 out of 75 samples) were the most prevalent ARGs detected even though both genes were detected only in a fraction of the samples. The mean concentrations were 5 genes $\times 10^{6} 16 \mathrm{~S}$ rDNA copies ${ }^{-1}$ and 15 genes $\times$ $10^{6} 16 \mathrm{~S}$ rDNA copies ${ }^{-1}$ for sulI and ermB respectively for the samples which had high 
enough concentration for quantification (6 samples sulI and 3 samples for ermB). ARG dfrAl was also detected, but only in 1 sample. No other ARGs could be detected. intIl was quantified in all samples at mean concentration of 38,000 genes $\times 10^{6} 16 \mathrm{~S}$ rDNA copies ${ }^{-1}$. Overall, the ARG concentrations were lower than what was observed in the wetlands used in Paper III with the exception of ermB which were found at about the same concentration levels. No effect of the antibiotic exposure could be observed on ARG or intII concentrations in any of the microcosms, which was also in line with what was found in the wetland experiment in Paper III.

The background levels of ARGs measured in the sediments were indicative of only slight environmental impact. That no effect from the low antibiotic concentrations could be observed on abundances of ARGs and integrons was consistent with the findings in Paper III. However, the microcosms exposed to 1,000 times the concentrations used in the wetlands in Paper III also did not exhibit increased levels of ARGs or integrons. This is noteworthy as the concentrations of many of the antibiotics used in these microcosms were in the range of MICs for reference strains (Andrews, 2001). Gullberg et al., 2011, determined minimum selective concentrations for some bacterial strains which were exceeded in the 1000x microcosms (approximately six times and one hundred times for tetracycline and ciprofloxacin respectively). The discrepancies in the results could be explained by the fact that the experimental environment in Paper IV consisted of bacterial strains which possible had higher tolerance against antibiotics. It is also likely that minimum selective concentrations can differ in complex bacterial communities. It can also not be ruled out that the bacteria developed antibiotic resistance, either by acquiring ARGs which were not analysed for in the experiment, or by the acquisition of resistance-yielding point mutations. In Wright et al., 2008, intII concentrations were shown to increase when microcosms constructed from river water were exposed to tetracycline. The tetracycline resistance concentrations used in those microcosms were 300 times those used in Paper IV however. Amongst the different environments investigated in Papers I-IV, the lake sediments used for the microcosms contained the lowest levels of ARGs. It might be that no increase in ARG abundance, even in the microcosms with the highest antibiotic concentrations, could be observed because essential ARGs were not present in the environment to be selected for. 


\section{Closing discussion}

It is becoming increasingly clear that the environment plays an important role in the dissemination of antibiotic resistance. In Papers I-IV, ARGs were detected in all environments analysed. This included aquatic environments practically undisturbed by human activities, although the abundances of ARGs tended to be lower in these environments. Other studies have also discovered ARGs in locations previously untouched by human hands (D'Costa et al., 2011; Bhullar et al., 2012). Clearly, ARGs are ubiquitous in aquatic environments. As antibiotics are regularly discharged into the environment via urban waste, it prompts the question what effect these compounds will have on the abundance and dissemination of the indigenous ARGs. It has been observed that environments exposed to extremely high levels of antibiotics, e.g. close to drug manufacturing plants, also have high levels of ARGs (Li et al., 2010; Kristiansson et al., 2011). Very high levels of antibiotics and corresponding ARGs were observed near a drug formulation facility in Pakistan in Paper I, suggesting that it is very likely that ARGs are selected for in environments highly contaminated with antibiotics.

Antibiotic concentrations in common urban wastewater are usually of lower levels; concentrations in $n g \times \mathrm{L}^{-1}$ to low $\mu \mathrm{g} \times \mathrm{L}^{-1}$ are commonly measured (Segura et al., 2009). At these levels, the effect on ARG abundances and on bacteria in general, is more difficult to ascertain. Although it has been shown that resistant bacteria can be selected for at concentrations lower than MICs (Gullberg et al., 2011), antibiotic concentrations in wastewater are usually measured at concentrations about 1 to 2 orders of magnitude lower (the lowest minimum selective concentration observed for ciprofloxacin was however within this range). In Papers I-II, it was shown that ARG concentrations increased in environments affected by human activities. More specifically, ARG concentrations were shown to increase in two separate river systems, downstream of a point of clear anthropogenic impact. In Paper I, ARG levels increased in the river Ravi, Pakistan, as it flowed through the city Lahore. In Paper II, ARG levels likewise increased in the river Stångån, Sweden, as it flowed through the city Linköping. While the ARG concentrations (and antibiotic concentrations) clearly increased downstream in these river systems, it is by no means clear that the cause of the increase is the antibiotics themselves. In Papers III-IV, environments previously unexposed to antibiotics were contaminated with mixtures of antibiotics of varying concentrations in the range of what is commonly found in wastewater, to determine the fate of the antibiotics, and if any effect on ARGs could be observed. The surface-flow CWs in Paper III were efficient at removing antibiotics at concentrations similar to what is commonly encountered in wastewater. In neither the CW system studied in Paper III nor the lake sediment microcosms studied in Paper IV, could any effect of the antibiotic mixtures used be observed on ARG concentrations, even though 
the background abundances of ARGs were comparable to the anthropogenically unperturbed aquatic environments studied in Papers I-II. The experimental set-ups in Papers III-IV did however differ on a few points which could explain the discrepancies. Firstly, fewer antibiotics were used in the controlled experiments, and synergy effects may be important. Secondly, while the antibiotic concentrations used were similar to a wastewater environment, the mode of application was not. In a wastewater system, indigenous bacteria are likely to be exposed to antibiotics in an inhomogeneous fashion, with concentrations varying from day to day, and over a longer period of time. These could potentially be important factors. Lastly, in the experiments, the mixtures added contained only antibiotics and no other compounds. In a wastewater system, waste accumulated from the surrounding urban milieu would include all manner of confounding factors. This includes bacteria and ARGs. In the case of Papers I-II, ARGs are observed to increase in rivers after a point at which the rivers receive an accumulation of human waste from the adjacent urban environment. It may be that the increase in ARGs is not due to selection in the wastewater by means of the increased levels of antibiotics, but simply because ARGs may have accumulated from different point sources within the cities.

Integrons are also, like ARGs, ubiquitous in aquatic environments. Class 1 integrons were detected at all sampling sites in Papers I-IV, including the least anthropogenically impacted sites. As with ARGs, the concentrations of class 1 integrons were elevated in anthropogenically impacted environments, a phenomenon which has been observed in several earlier studies (Wright et al., 2008; Rosewarne et al., 2010; Gaze et al., 2011). The trends of abundances of class 1 integrons reflected the trends of the ARGs in Papers I-IV, with increases in rivers downstream the anthropogenic exposure in Papers I-II and the lack of effect observed on the concentrations due to the antibiotic exposure in the experimental systems in Papers III-IV. That class 1 integron concentrations correlate with ARGs could at least partly be explained by noting that ARGs (at least the sulI gene) may be associated with class 1 integron as integron cassettes. The sequencing of class 1 integron gene cassettes in Paper III revealed that at the most abundant gene cassettes were unlikely to code for resistance functions. It is reasonable to assume that class 1 integrons in environments unexposed to antibiotics are likelier to code for functions other than antibiotic resistance. This can be compared to the highly contaminated site close to the drug formulation facility in Paper I. At this site, antibiotics are presumably an environmental factor of high impact on bacterial survival. This is evidenced not only by the high concentrations of antibiotics, but also by the accompanying high concentrations of ARGs. Interestingly, concentrations of class 1 integrons were also extremely high at this site, which may suggest that class 1 integrons play an important role in disseminating ARGs in highly contaminated environments. 
The results presented in this thesis indicate that at least for high concentrations of antibiotics, contamination plays an important role in contributing to increasing levels of ARG concentrations in anthropogenically affected aquatic environments. Thus, keeping down the antibiotic pollution levels is clearly important. While low levels of antibiotics do not necessarily impact ARG abundance and dissemination, at some point the levels get high enough to do just that. More studies are needed to investigate what those concentrations levels are, and also how they are likely to differ in different environments with different bacterial communities. Knowledge of these levels may prevent an environmental proliferation of ARGs which may eventually exacerbate resistance prevalence in pathogenic bacteria. All in all, understanding the role of the environment in the dissemination of ARGs may be essential to effectively combat the rising threat of antibiotic resistance. 


\section{Conclusions}

- ARGs and class 1 integrons are ubiquitous in both aquatic environments heavily affected by anthropogenic waste and aquatic environments only lightly affected by anthropogenic activities.

- High concentrations of antibiotics released into urban aquatic environments are likely to increase ARG and class 1 integron abundances.

- Low concentrations of antibiotics released into aquatic environments are unlikely to significantly impact the bacterial community and development of ARGs.

- Surface-flow CWs can be useful as supplements to conventional wastewater treatment for reducing low concentrations of antibiotics in treated wastewater. 


\section{Acknowledgements}

I would like to thank my main supervisor Per-Eric Lindgren and all the people in his research group, past and present.

I also thank our collaborators at Department of Chemistry, Umeå University, Jerker Fick (co-supervisor) and Ghazanfar Ali Khan, for fruitful scientific discussions and for contributing with their expertise in chemical analyses. I also thank my co-supervisor Björn Olsen at Clinical Microbiology and Infectious Medicine, Uppsala University, for giving me the opportunity to participate in many interesting projects.

I also thank our collaborators at Halmstad University, Stefan Weisner and Per Magnus Ehde, for providing us with the opportunity for on-site wetland studies, as well as their scientific input and help with sampling.

Finally, I also would like to thank the staff at the division for Medical Microbiology, Linköping University, past and present, for creating a nice workplace.

I thank the Swedish Research Council for Environment, Agricultural Sciences and Spatial Planning (Formas) and the Foundation for Strategic Environmental Research (MISTRA) for financial support. 


\section{References}

Abrams, E.S. and Stanton, V.P. Jr. (1992) Use of denaturing gradient gel electrophoresis to study conformational transitions in nucleic acids. Methods Enzymol. 212:71-104.

Abuin, S., Codony, R., Compañó, R., Granados, M. and Prat, M.D. (2006) Analysis of macrolide antibiotics in river water by solid-phase extraction and liquid chromatography-mass spectrometry. J. Chromatogr. A. 1114(1):73-81.

Alekshun, M.N. and Levy, S.B. (2007) Molecular mechanisms of antibacterial multidrug resistance. Cell. 128(6):1037-1050.

Allen, H.K., Donato, J., Wang, H.H., Cloud-Hansen, K.A., Davies, J. and Handelsman, J. (2010) Call of the wild: antibiotic resistance genes in natural environments. Nat. Rev. Microbiol. 8(4):251-259.

Aminov, R.I. (2009) The role of antibiotics and antibiotic resistance in nature. Environ. Microbiol. 11(12):2970-2988.

Andersson, D.I. and Hughes, D. (2012) Evolution of antibiotic resistance at non-lethal drug concentrations. Drug Resist. Updat. 15(3):162-172.

Andrews, J.M. (2001) Determination of minimum inhibitory concentrations. J. Antimicrob. Chemother. 48 Suppl 1:5-16.

Appelbaum, P.C. (2012) 2012 and beyond: potential for the start of a second pre-antibiotic era? J. Antimicrob. Chemother. 67(9):2062-2068.

Appelbaum, P.C. and Hunter, P.A. (2000) The fluoroquinolone antibacterials: past, present and future perspectives. Int. J. Antimicrob. Agents. 16(1):5-15.

Araújo, C., Torres, C., Silva, N., Carneiro, C., Gonçalves, A., Radhouani, H., Correia, S., da Costa, P.M., Zarazaga, M., Ruiz-Larrea, F., Poeta, P. and Igrejas, G. (2010) Vancomycin-resistant enterococci from Portuguese wastewater treatment plants. J. Basic Microbiol. 50(6):605-609.

Ardley, R.E. (2003) Liquid chromatography. In Liquid chromatography-mass spectrometry: an introduction, edited by Ando, D.J., John Wiley \& Sons, Hoboken, pp 7-31.

Aronsson, B., Boscan, I.S., Cars, O., Giamarellou, H., Gyssens, I.C., Lutsar, I., Monnet, D.L., Norrby, R. and Powell, M. (2009) The bacterial challenge: time to react. European Centre for Disease Prevention \& Control and the European Medicines Agency, Stockholm (Sweden). Report No.: EMEA/576176/2009.

Auerbach, E.A., Seyfried, E.E. and McMahon, K.D. (2007) Tetracycline resistance genes in activated sludge wastewater treatment plants. Water Res. 41(5):1143-1151.

Baharoglu, Z., Bikard, D. and Mazel, D. Conjugative DNA transfer induces the bacterial SOS response and promotes antibiotic resistance development through integron activation. PLoS. Genet. 6(10):e1001165.

Baquero, F., Martínez, J.L. and Cantón, R. (2008) Antibiotics and antibiotic resistance in water environments. Curr. Opin. Biotechnol. 19(3):260-265.

Bates, S., Cashmore, A.M. and Wilkins, B.M. (1998) IncP plasmids are unusually effective in mediating conjugation of Escherichia coli and Saccharomyces cerevisiae: involvement of the tra2 mating system. $J$. Bacteriol. 180(24):6538-6543. 
Bennett, P.M. (2008) Plasmid encoded antibiotic resistance: acquisition and transfer of antibiotic resistance genes in bacteria. Br. J. Pharmacol. 153 Suppl 1:S347-357.

Bernier, S.P. and Surette, M.G. (2013) Concentration-dependent activity of antibiotics in natural environments. Front. Microbiol. 4:20.

Bhullar, K., Waglechner, N., Pawlowski, A., Koteva, K., Banks, E.D., Johnston, M.D., Barton, H.A. and Wright, G.D. (2012) Antibiotic resistance is prevalent in an isolated cave microbiome. PLoS. One. 7(4):e34953.

Bjørheim, J., Gaudernack, G. and Ekstrøm, P.O. (2002) Melting gel techniques in single nucleotide polymorphism and mutation detection: From theory to automation. J. Sep. Sci. 25:637-647.

Blomberg, B. (2008) Antibiotikaresistens i utviklingsland. Tidsskr. Nor. Laegeforen. 128(21):246-2466.

Boon, N., Windt, W., Verstraete, W. and Top, E.M. (2002) Evaluation of nested PCR-DGGE (denaturing gradient gel electrophoresis) with group-specific $16 \mathrm{~S}$ rRNA primers for the analysis of bacterial communities from different wastewater treatment plants. FEMS Microbiol. Ecol. 39(2):101-112.

Borgen, K., Simonsen, G.S., Sundsfjord, A., Wasteson, Y., Olsvik, O. and Kruse, H. (2000) Continuing high prevalence of VanA-type vancomycin-resistant enterococci on Norwegian poultry farms three years after avoparcin was banned. J. Appl. Microbiol. 89(3):478-485.

Brigulla, M. and Wackernagel, W. (2010) Molecular aspects of gene transfer and foreign DNA acquisition in prokaryotes with regard to safety issues. Appl. Microbiol. Biotechnol. 86(4):1027-1041.

Brüssow, H. and Hendrix, R.W. (2002) Phage genomics: small is beautiful. Cell. 108(1):13-16.

Bugg, T.D., Braddick, D., Dowson, C.G. and Roper, D.I. (2011) Bacterial cell wall assembly: still an attractive antibacterial target. Trends Biotechnol. 29(4):167-173.

Burrus, V., Pavlovic, G., Decaris, B. and Guédon G. (2002) Conjugative transposons: the tip of the iceberg. Mol. Microbiol. 46(3):601-610.

Bönemann, G., Stiens, M., Pühler, A. and Schlüter A. (2006) Mobilizable IncQ-related plasmid carrying a new quinolone resistance gene, qnrS2, isolated from the bacterial community of a wastewater treatment plant. Antimicrob. Agents Chemother. 50(9):3075-3080.

Cambray, G., Guerout, A.M. and Mazel, D. (2010) Integrons. Annu. Rev. Genet. 44:141-166.

Caplin, J.L., Hanlon, G.W. and Taylor, H.D. (2008) Presence of vancomycin and ampicillin-resistant Enterococcus faecium of epidemic clonal complex-17 in wastewaters from the south coast of England. Environ. Microbiol. 10(4):885-892.

Carattoli, A. (2011) Plasmids in Gram negatives: molecular typing of resistance plasmids. Int. J. Med. Microbiol. 301(8):654-658.

Cattoir, V., Poirel, L., Rotimi, V., Soussy, C.J. and Nordmann, P. (2007) Multiplex PCR for detection of plasmid-mediated quinolone resistance qnr genes in ESBL-producing enterobacterial isolates. J. Antimicrob. Chemother. 60(2):394-397.

Cattoir, V., Poirel, L., Aubert, C., Soussy, C.J. and Nordmann, P. (2008) Unexpected occurrence of plasmid-mediated quinolone resistance determinants in environmental Aeromonas spp. Emerg. Infect. Dis. 14(2):231-237.

Chen, I., Christie, P.J. and Dubnau, D. (2005) The ins and outs of DNA transfer in bacteria. Science. 310(5753):1456-1460. 
Chen, I. and Dubnau, D. (2004) DNA uptake during bacterial transformation. Nat Rev Microbiol. 2(3):241-249.

Chen, J., Yu, Z., Michel, F.C. Jr, Wittum, T. and Morrison, M. (2007) Development and application of real-time PCR assays for quantification of erm genes conferring resistance to macrolides-lincosamides-streptogramin $\mathrm{B}$ in livestock manure and manure management systems. Appl. Environ. Microbiol. 73(14):4407-4416.

Chopra, I. and Roberts, M. (2001) Tetracycline Antibiotics: Mode of Action, Applications, Molecular Biology, and Epidemiology of Bacterial Resistance. Microbiol. Mol. Biol. Rev. 65(2):232-260.

Colomer-Lluch, M., Jofre, J. and Muniesa, M. (2011) Antibiotic resistance genes in the bacteriophage DNA fraction of environmental samples. PLoS. One. 6(3):e17549.

Courvalin, P. (2006) Vancomycin resistance in Gram-positive cocci. Clin. Infect. Dis. 42 Suppl 1:S25-34.

Cummings, D.E., Archer, K.F., Arriola, D.J., Baker, P.A., Faucett, K.G., Laroya, J.B., Pfeil, K.L., Ryan, C.R. and Zuill, D.E. (2011) Broad dissemination of plasmid-mediated quinolone resistance genes in sediments of two urban coastal wetlands. Environ. Sci. Technol. 45(2):447-454.

Curcio, M.J. and Derbyshire, K.M. (2003) The outs and ins of transposition: from mu to kangaroo. Nat. Rev. Mol. Cell. Biol. 4(11):865-877.

Damodaran, S.E. and Madhan, S. (2011) Telavancin: A novel lipoglycopeptide antibiotic. J. Pharmacol. Pharmacother. 2(2):135-137.

Dalkmann, P., Broszat, M., Siebe, C., Willaschek, E., Sakinc, T., Huebner, J., Amelung, W., Grohmann, E. and Siemens, J. (2012) Accumulation of pharmaceuticals, Enterococcus, and resistance genes in soils irrigated with wastewater from zero to 100 years in central Mexico. PLoS One. 7(9):e45397.

Davies, J. (2006) Are antibiotics naturally antibiotics? J. Ind. Microbiol. Biotechnol. 33(7):496-499.

Davies, J. (2010) The garden of antimicrobial delights. F1000 Biol. Rep. 2:26.

Davies, J. and Davies, D. (2010) Origins and evolution of antibiotic resistance. Microbiol. Mol. Biol. Rev. 74(3):417-433.

Davison, J. (1999) Genetic exchange between bacteria in the environment. Plasmid. 42(2):73-91.

D’Costa, V.M., King, C.E., Kalan, L., Morar, M., Sung, W.W., Schwarz, C., Froese, D., Zazula, G., Calmels, F., Debruyne, R., Golding, G.B., Poinar, H.N. and Wright, G.D. (2011) Antibiotic resistance is ancient. Nature. 477(7365):457-461.

Devanshu, S., Rahul, M., Annu, G., Kishan, S. and Anroop, N. (2010) Quantitative bioanalysis by LC-MS/MS: A review. J. Pharm. Biomed. Sci. 7(1):1-9.

Domingues, S., da Silva, G.J. and Nielsen, K.M. (2012a) Integrons: Vehicles and pathways for horizontal dissemination in bacteria. Mob. Genet. Elements. 2(5):211-223.

Domingues, S., Harms, K., Fricke, W.F., Johnsen, P.J., da Silva G.J. and Nielsen, K.M. (2012b) Natural transformation facilitates transfer of transposons, integrons and gene cassettes between bacterial species. PLoS Pathog. 8(8):e1002837. 
Duarte, R.S., Miranda, O.P., Bellei, B.C., Brito, M.A. and Teixeira, L.M. (2004) Phenotypic and molecular characteristics of Streptococcus agalactiae isolates recovered from milk of dairy cows in Brazil. J. Clin. Microbiol. 42(9):4214-4222.

Forcella, C., Pellegrini, C., Celenza, G., Segatore, B., Calabrese, R., Tavio, M.M., Amicosante, G., and Perilli, M. (2010) QnrB9 in association with TEM-116 extended-spectrum beta-lactamase in Citrobacter freundii isolated from sewage effluent: first report from Italy. J. Chemother. 22(4):243-245.

Froelich-Ammon, S.J. and Osheroff, N. (1995) Topoisomerase poisons: harnessing the dark side of enzyme mechanism. J. Biol. Chem. 270(37):21429-21332.

Fromin, N., Hamelin, J., Tarnawski, S., Roesti, D., Jourdain-Miserez, K., Forestier, N., Teyssier-Cuvelle, S., Gillet, F., Aragno, M. and Rossi, P. (2002) Statistical analysis of denaturing gel electrophoresis (DGE) fingerprinting patterns. Environ. Microbiol. 4(11):634-643.

Gafan, G.P., Lucas, V.S., Roberts, G.J., Petrie, A., Wilson, M. and Spratt, D.A. (2005) Statistical analyses of complex denaturing gradient gel electrophoresis profiles. J. Clin. Microbiol. 43(8):3971-3978.

Gao, P., Munir, M. and Xagoraraki, I. (2012) Correlation of tetracycline and sulfonamide antibiotics with corresponding resistance genes and resistant bacteria in a conventional municipal wastewater treatment plant. Sci. Tot. Environ. 421-422:173-183.

Gaze, W.H., Zhang, L., Abdouslam, N.A., Hawkey, P.M., Calvo-Bado, L., Royle, J., Brown, H., Davis, S., Kay, P., Boxall, A.B. and Wellington, E.M. (2011) Impacts of anthropogenic activity on the ecology of class 1 integrons and integron-associated genes in the environment. ISME J. 5(8):1253-1261.

Ginzinger, D.G. (2002) Gene quantification using real-time quantitative PCR: an emerging technology hits the mainstream. Exp. Hematol. 30(6):503-512.

Grohmann, E., Muth, G. and Espinosa, M. (2003) Conjugative plasmid transfer in Gram-positive bacteria. Microbiol. Mol. Biol. Rev. 67(2):277-301.

Gros, M., Petrović and Barceló, D. (2006) Multi-residue analytical methods using LC-tandem MS for the determination of pharmaceuticals in environmental and wastewater samples: a review. Anal. Bioanal. Chem. 386(4):941-952.

Guerin, E., Cambray, G., Sanchez-Alberola, N., Campoy, S., Erill, I., Da Re, S., Gonzalez-Zorn, B., Barbé, J., Ploy, M.C. and Mazel, D. (2009) The SOS response controls integron recombination. Science. 324(5930):1034.

Gullberg, E., Cao, S., Berg, O.G., Ilbäck, C., Sandegren, L., Hughes, D. and Andersson, D.I. (2011) Selection of resistant bacteria at very low antibiotic concentrations. PLoS Pathog. 7(7):e1002158.

Halling-Sørensen, B., Nors Nielsen, S., Lanzky, P.F., Ingerslev, F., Holten Lützhøft, H.C. and Jørgensen, S.E. (1998) Occurence, fate and effects of pharmaceutical substances in the environment $-\mathrm{a}$ review. Chemosphere. 36(2)357-393.

Hawkey, P.M. (2003) Mechanisms of quinolone action and microbial response. J. Antimicrob. Chemother. 51 Suppl 1:29-35.

Hawkey, P.M. (2008) The growing burden of antimicrobial resistance. J. Antimicrob. Chemother. 62 Suppl $1:$ i1-9.

Hawser, S., Lociuro, S. and Islam, K. (2006) Dihydrofolate reductase inhibitors as antibacterial agents. Biochem. Pharmacol. 71(7):941-948. 
Hayes, J.R., Wagner, D.D., English, L.L., Carr, L.E. and Joseph, S.W. (2005) Distribution of streptogramin resistance determinants among Enterococcus faecium from a poultry production environment of the USA. $J$. Antimicrob. Chemother. 55(1):123-126.

Henriques, I.S., Fonseca, F., Alves, A., Saavedra, M.J. and Correia, A. (2006) Occurrence and diversity of integrons and beta-lactamase genes among ampicillin-resistant isolates from estuarine waters. Res. Microbiol. 157(10):938-947.

Hindson, B.J., Ness, K.D., Masquelier, D.A., Belgrader, P., Heredia, N.J., Makarewicz, A.J., Bright, I.J., Lucero, M.Y., Hiddessen, A.L., Legler, T.C., Kitano, T.K., Hodel, M.R., Petersen, J.F., Wyatt, P.W., Steenblock, E.R., Shah, P.H., Bousse, L.J., Troup, C.B., Mellen, J.C., Wittmann, D.K., Erndt, N.G., Cauley, T.H., Koehler, R.T., So, A.P., Dube, S., Rose, K.A., Montesclaros, L., Wang, S., Stumbo, D.P., Hodges, S.P., Romine, S., Milanovich, F.P., White, H.E., Regan, J.F., Karlin-Neumann, G.A., Hindson, C.M., Saxonov, S. and Colston, B.W. (2011) High-throughput droplet digital PCR system for absolute quantitation of DNA copy number. Anal. Chem. 83(22):8604-8610.

Ho, C.S., Lam, C.W., Chan, M.H., Cheung, R.C., Law, L.K., Lit, L.C., Ng, K.F., Suen, M.W. and Tai, H.L. (2003) Electrospray ionization mass spectrometry: principles and clinical applications. Clin. Biochem. Rev. 24(1):3-12.

Hughes, S.R., Kay, P. And Brown, L.E. (2013) Global synthesis and critical evaluation of pharmaceutical data sets collected from river systems. Environ. Sci. Technol. 47(2):661-677.

Huovinen, P. (1987) Trimethoprim resistance. Antimicrob. Agents Chemother. 31(10):1451-1456.

Huovinen, P., Sundström, L., Swedberg, G. and Sköld, O. (1995) Trimethoprim and sulfonamide resistance. Antimicrob. Agents Chemother. 39(2):279-289.

Ibekwe, A.M., Lyon, S.R., Leddy, M. and Jacobsen-Meyers, M. (2007) Impact of plant density and microbial composition on water quality from a free water surface constructed wetland. J. Appl. Microbiol. 102(4):921-936.

Iversen, A., Kühn, I., Franklin, A. and Möllby, R. (2002) High prevalence of vancomycin-resistant enterococci in Swedish sewage. Appl. Environ. Microbiol. 68(6):2838-2842.

Jensen, E.C., Schrader, H.S., Rieland, B., Thompson, T.L., Lee, K.W., Nickerson, K.W. and Kokjohn, T.A. (1998) Prevalence of broad-host-range lytic bacteriophages of Sphaerotilus natans, Escherichia coli, and Pseudomonas aeruginosa. Appl. Environ. Microbiol. 64(2):575-580.

Jiang, S.C. and Paul, J.H. (1998) Gene transfer by transduction in the marine environment. Appl. Environ. Microbiol. 64(8):2780-2787.

Johnsborg, O., Eldholm, V. and Håvarstein, L.S. (2007) Natural genetic transformation: prevalence, mechanisms and function. Res Microbiol. 158(10):767-778.

Johnsborg, O., and Håvarstein, L.S. (2009) Regulation of natural genetic transformation and acquisition of transforming DNA in Streptococcus pneumonia. FEMS Microbiol. Rev. 33(3):627-642.

Jung, H.M., Jeya, M., Kim, S.Y., Moon, H.J., Kumar Singh, R., Zhang, Y.W. and Lee, J.K. (2009) Biosynthesis, biotechnological production, and application of teicoplanin: current state and perspectives. Appl. Microbiol. Biotechnol. 84(3):417-428.

Kirst, H.A. (2001) Introduction to the macrolide antibiotics. In Macrolide Antibiotics, edited by Schonfeld, W. and Kirst, H.A., Birkhauser Verlag, Boston, pp 1-14.

Knapp, C.W., Dolfing, J., Ehlert, P.A. and Graham, D.W. (2010) Evidence of increasing antibiotic resistance gene abundances in archived soils since 1940. Environ. Sci. Technol. 44(2):580-587. 
Koenig, J.E., Boucher, Y., Charlebois, R.L., Nesbø, C., Zhaxybayeva, O., Bapteste, E., Spencer, M., Joss, M.J., Stokes, H.W. and Doolittle, W.F. (2008) Integron-associated gene cassettes in Halifax Harbour: assessment of a mobile gene pool in marine sediments. Environ. Microbiol. 10(4):1024-1038.

Kolpin, D.W., Furlong, E.T., Meyer, M.T., Thurman, E.M., Zaugg, S.D., Barber, L.B. and Buxton, H.T. (2002) Pharmaceuticals, hormones, and other organic wastewatercontaminants in U.S. streams, 1999-2000: a national reconnaissance. Environ. Sci. Technol. 36(6):1202-1211.

Kristiansson, E., Fick, J., Janzon, A., Grabic, R., Rutgersson, C., Weijdegård, B., Söderström, H. and Larsson, D.G. (2011) Pyrosequencing of antibiotic-contaminated river sediments reveals high levels of resistance and gene transfer elements. PLoS One. 6(2):e17038.

Kubista, M., Andrade, J.M., Bengtsson, M., Forootan, A., Jonák, J., Lind, K., Sindelka, R., Sjöback, R., Sjögreen, B., Strömbom, L., Ståhlberg, A. and Zoric, N. (2006) The real-time polymerase chain reaction. Mol. Aspects Med. 27(2-3):95-125.

Kümmerer. K. (2004) Resistance in the environment. J. Antimicrob. Chemother. 54(2):311-320.

Kushnir, M.M., Rockwood, A.L., Roberts, W.L., Yue, B., Bergquist, J. and Meikle, A.W. (2011) Liquid chromatography tandem mass spectrometry for analysis of steroids in clinical laboratories. Clin. Biochem. 44(1):77-88.

Larsson, D.G., de Pedro, C. and Paxeus, N. (2007) Effluent from drug manufactures contains extremely high levels of pharmaceuticals. J. Hazard. Mater. 148(3):751-755.

Lavilla, S., González-López, J.J., Sabaté, M., García-Fernández, A., Larrosa, M.N., Bartolomé, R.M., Carattoli, A. and Prats, G. (2008) Prevalence of qnr genes among extended-spectrum beta-lactamase-producing enterobacterial isolates in Barcelona, Spain. J. Antimicrob. Chemother. 61(2):291-295.

Laxminarayan, R.,Bhutta, Z., Duse, A., Jenkins, P., O’Brien, T., Okeke, I.N., Pablo-Mendez, A. and Klugman, K.P. (2006) Drug resistance. In Disease control priorities in developing countries, edited by Jamison, D.T., Breman, J.G., Measham, A.R., Alleyne, G., Claeson, M., Evans, D.B., Jha, P., Mills, A. and Musgrove, P., World Bank, Washington (DC), pp 1031-1051.

Levine, D.P. (2006) Vancomycin: a history. Clin. Infect. Dis. 42 Suppl 1:S5-12.

Levy, S.B. and Marshall, B. (2004) Antibacterial resistance worldwide: causes, challenges and responses. Nat. Med. 10(12 Suppl):S122-129.

Lewis, K. (2009) Persisters, biofilms, and the Problem of Cultivability. In Uncultivated Microorganisms, edited by Epstein, S.S., Springer-Verlag, Berlin, Heidelberg, pp 182-194.

Li, D., Yang, M., Hu, J., Ren, L., Zhang, Y. and Li, K. (2008) Determination and fate of oxytetracycline related compounds in oxytetracycline production wastewater and the receiving river. Environ. Toxicol. Chem. 27(1):80-86.

Li, D., Yu, T., Zhang, Y., Yang, M., Li, Z., Liu, M. and Qi, R. (2010) Antibiotic resistance characteristics of environmental bacteria from an oxytetracycline production wastewater treatment plant and the receiving river. Appl. Environ. Microbiol. 76(11):3444-3451.

Mahillon, J. and Chandler, M. (1998) Insertion sequences. Microbiol. Mol. Biol. Rev. 62(3):725-774. 
Mao, D., Luo, Y., Mathieu, J., Wang, Q., Feng, L., Mu, Q., Feng, C. and Alvarez, P.J. Persistence of extracellular DNA in river sediment facilitates antibiotic resistance gene propagation. Environ. Sci. Technol. 48(1):71-78.

Marti, E., Jofre, J. And Balcazar, J.L. (2013) Prevalence of antibiotic resistance genes and bacterial community composition in a river influenced by a wastewater treatment plant. PLoS One. 8(10):e78906.

Martínez, J.L. (2008) Antibiotics and antibiotic resistance genes in natural environments. Science. 321(5887):365-367.

Martínez, J.L. (2009) The role of natural environments in the evolution of resistance traits in pathogenic bacteria. Proc. Biol. Sci. 276(1667):2521-2530.

Martínez, J.L. (2012) Natural antibiotic resistance and contamination by antibiotic resistance determinants: the two ages in the evolution of resistance to antimicrobials. Front. Microbiol. 3:1-3.

Maurin, M. (2012) Real-time PCR as a diagnostic tool for bacterial diseases. Expert Rev. Mol. Diagn. 12(7):731-754.

Mazel, D. (2006) Integrons: agents of bacterial evolution. Nat. Rev. Microbiol. 4(8):608-620.

Messi, P., Guerrieri, E., de Niederhäusern, S., Sabia, C. and Bondi, M. (2006) Vancomycin-resistant enterococci (VRE) in meat and environmental samples. Int. J. Food Microbiol. 107(2):218-222.

Michael, C.A., Gillings, M.R., Holmes, A.J., Hughes, L., Andrew, N.R., Holley, M.P. and Stokes, H.W. (2004) Mobile gene cassettes: a fundamental resource for bacterial evolution. Am. Nat. 164(1):1-12.

Moura, A., Henriques, I., Ribeiro, R. and Correia, A. (2007) Prevalence and characterization of integrons from bacteria isolated from a slaughterhouse wastewater treatment plant. J. Antimicrob. Chemother. 60(6):1243-1250.

Mullis, K.B. and Faloona, F.A. (1987) Specific synthesis of DNA in vitro via a polymerase-catalyzed chain reaction. Methods Enzymol. 155:335-350.

Mukherjee, S. and Chakraborty, R. (2006) Incidence of class 1 integrons in multiple antibiotic-resistant Gram-negative copiotrophic bacteria from the River Torsa in India. Res. Microbiol. 157(3):220-226.

Muniesa, M., Colomer-Lluch, M., and Jofre, J. (2013) Could bacteriophages transfer antibiotic resistance genes from environmental bacteria to human-body associated bacterial populations? Mob. Genet. Elements. 3(4):e25847.

Muyzer, G., de Waal, E.C. and Uitterlinden, A.G. (1993) Profiling of complex microbial populations by denaturing gradient gel electrophoresis analysis of polymerase chain reaction-amplified genes coding for $16 \mathrm{~S}$ rRNA. Appl. Environ. Microbiol. 59(3):695-700.

Nazarenko, I., Lowe, B., Darfler, M., Ikonomi, P., Schuster, D. and Rashtchian, A. (2002) Multiplex quantitative PCR using self-quenched primers labeled with a single fluorophore. Nucleic Acids Res. 30(9):e37.

Nelson, M.L. and Levy, S.B. (2011) The history of tetracyclines. Ann. N. Y. Acad. Sci. 1241:17-32.

Niessen, W.M. (2003) Progress in liquid chromatography-mass spectrometry instrumentation and its impact on high-throughput screening. J. Chromatogr. A. 1000(1-2):413-436. 
Nilsson, O., Greko, C., Bengtsson, B. and Englund, S. (2012) Genetic diversity among VRE isolates from Swedish broilers with the coincidental finding of transferrable decreased susceptibility to narasin. J. Appl. Microbiol. 112(4):716-722.

Novais, C., Coque, T.M., Costa, M.J., Sousa, J.C., Baquero, F. and Peixe, L.V. (2005) High occurrence and persistence of antibiotic-resistant enterococci in poultry food samples in Portugal. J. Antimicrob. Chemother. 56(6):1139-1143.

Ozgumus, O.B., Sandalli, C., Sevim, A., Celik-Sevim, E. and Sivri, N. (2009) Class 1 and class 2 integrons and plasmid-mediated antibiotic resistance in coliforms isolated from ten rivers in northern Turkey. $J$. Microbiol. 47(1):19-27.

Pallecchi, L., Riccobono, E., Mantella, A., Bartalesi, F., Sennati, S., Gambo, H., Gotuzzo, E., Bartoloni, A. and Rossolini, G.M. (2009) High prevalence of qnr genes in commensal enterobacteria from healthy children in Peru and Bolivia. Antimicrob. Agents Chemother. 53(6):2632-2635.

Pei, R., Kim, S.C., Carlson, K.H. and Pruden, A. (2006) Effect of river landscape on the sediment concentrations of antibiotics and corresponding antibiotic resistance genes (ARG). Water Res. 40(12):2427-2435.

Périchon, B. and Courvalin, P. (2009) VanA-type vancomycin-resistance Staphylococcus aureus. Antimicrob. Agents Chemother. 53(11):4580-4587.

Phillips, I., Casewell, M., Cox, T., De Groot, B., Friis, C., Jones, R., Nightingale, C., Preston, R. and Waddell, J. (2004) Does the use of antibiotics in food animals pose a risk to human health? A critical review of published data. J. Antimicrob. Chemother. 53(1):28-52.

Picão, R.C., Poirel, L., Demarta, A., Silva, C.S., Corvaglia, A.R., Petrini, O. and Nordmann, P. (2008) Plasmid-mediated quinolone resistance in Aeromonas allosaccharophila recovered from a Swiss lake. $J$. Antimicrob. Chemother. 62(5):948-950.

Planta, M.B. (2007) The role of poverty in antimicrobial resistance. J. Am. Board Fam. Med. 20(6):533-539.

Prudhomme, M., Attaiech, L., Sanchez, G., Martin, B. And Claverys, J.P. (2006) Antibiotic stress induces genetic transformability in the human pathogen Streptococcus pneumonia. Science. 313(5783):89-92.

Roberts, A.P., Chandler, M., Courvalin, P., Guédon, G., Mullany, P., Pembroke, T., Rood, J.L., Smith, C.J., Summers, A.O., Tsuda, M. and Berg, D.E. (2008) Revised nomenclature for transposable elements. Plasmid. 60(3):167-173.

Roberts, A.P. and Mullany, P. (2009) A modular master on the move: the Tn916 family of mobile genetic elements. Trends Microbiol. 17(6):251-258.

Roberts, M.C. (2004) Resistance to macrolide, lincosamide, streptogramin, ketolide, and oxazolidinone antibiotics. Mol. Biotechnol. 28(1):47-62.

Roberts, M.C. (2005) Update on acquired tetracycline resistance genes. FEMS Microbiol. Lett. 245(2):195-203.

Roberts, M.C. (2008) Update on macrolide-lincosamide-streptogramin, ketolide and oxazolidinone resistance genes. FEMS Microbiol. Lett. 282(2):147-159.

Roberts, M.C., Soge, O.O., Giardino, M.A., Mazengia, E., Ma, G. and Meschke, J.S. (2009) Vancomycin-resistant Enterococcus spp. in marine environments from the West Coast of the USA. J. Appl. Microbiol. 107(1):300-307. 
Robicsek, A., Jacoby, G.A. and Hooper, D.C. (2006) The worldwide emergence of plasmid-mediated quinolone resistance. Lancet Infect. Dis. 6(10):629-640.

Robicsek, A., Strahilevitz, J., Sahm, D.F., Jacoby, G.A. and Hooper, D.C. (2006) qnr prevalence in ceftazidime-resistant Enterobacteriaceae isolates from the United States. Antimicrob. Agents Chemother. 50(8):2872-2874.

Rodríguez-Martínez, J.M., Cano, M.E., Velasco, C., Martínez-Martínez, L. and Pascual, A. (2011) Plasmid-mediated quinolone resistance: an update. J. Infect. Chemother. 17(2):149-182.

Rolain, J.M., Canton, R. and Cornaglia, G. (2012) Emergence of antibiotic resistance: need for a new paradigm. Clin. Microbiol. Infect. 18(7):615-616.

Rosewarne, C.P., Pettigrove, V., Stokes, H.W. and Parsons, Y.M. (2010) Class 1 integrons in benthic communities: abundance, association with Tn402-like transposition modules and evidence for coselection with heavy-metal resistance. FEMS Microbiol. Ecol. 72(1):35-46.

Salyers, A.A., Shoemaker, N.B., Stevens, A.M. and Li, L.Y. (1995) Conjugative transposons: an unusual and diverse set of integrated gene transfer elements. Microbiol. Rev. 59(4):579-590.

Schilling, A., Neuner, E. and Rehm, S.J. (2011) Vancomycin: a 50-something-year-old antibiotic we still don't understand. Cleve. Clin. J. Med. 78(7):465-471.

Scholz, M. and Lee, B.H. (2005) Constructed wetlands: a review. Int. J. Environ. Stud. 62(4):421-447.

Schwartz, T., Kohnen, W., Jansen, B. and Obst, U. (2003) Detection of antibiotic-resistant bacteria and their resistance genes in wastewater, surface water, and drinking water biofilms. FEMS Microbiol. Ecol. 43(3):325-335.

Segura, P.A., François, M.,Gagnon, C. and Sauvé, S. (2009) Review of the occurrence of anti-infectives in contaminated wastewaters and natural drinking waters. Environ. Health Perspect. 117(5):675-684.

Sengupta, S., Chattopadhyay, M.K. and Grossart, H.P. (2013) The multifaceted roles of antibiotics and antibiotic resistance in nature. Front. Microbiol. 4:47.

Sköld, O. (2001) Resistance to trimethoprim and sulfonamides. Vet. Res. 32(3-4):261-273.

Smillie, C., Garcillán-Barcia, M.P., Francia, M.V., Rocha, E.P. and de la Cruz, F. (2010) Mobility of plasmids. Microbiol. Mol. Biol. Rev. 74(3):434-452.

Stoll, C., Sidhu, J.P., Tiehm, A. and Toze, S. (2012) Prevalence of clinically relevant antibiotic resistance genes in surface water samples collected from Germany and Australia. Environ. Sci. Technol. 46(17):9716-9726.

Strahilevitz, J., Jacoby, G.A., Hooper, D.C. and Robicsek, A. (2009) Plasmid-mediated quinolone resistance: a multifaceted threat. Clin. Microbiol. Rev. 22(4):664-689.

Sundberg, C., Tonderski, K. and Lindgren, P.E. (2007) Potential nitrification and denitrification and the corresponding composition of the bacterial communities in a compact constructed wetland treating landfill leachates. Water Sci. Technol. 56(3):159-166.

Suzuki, S., Ogo, M., Miller, T.W., Shimizu, A., Takada, H. and Siringan, M.A. (2013) Who possesses drug resistance genes in aquatic environment?: sulfamethoxazole (SMX) resistance genes among the bacterial community in water environment of Metro-Manila, Philippines. Front. Microbiol. 4:102.

Szczepanowski, R., Krahn, I., Linke, B., Goesmann, A., Pühler, A. and Schlüter, A. (2004) Antibiotic multiresistance plasmid pRSB101 isolated from a wastewater treatment plant is related to plasmids residing 
in phytopathogenic bacteria and carries eight different resistance determinants including a multidrug transport system. Microbiology. 150:3613-3630.

Thaker, M., Spanogiannopoulos, P. and Wright, G.D. (2010) The tetracycline resistome. Cell. Mol. Life Sci. 67(3):419-431.

Touati, A., Brasme, L., Benallaoua, S., Gharout, A., Madous, J. and De Champs, C. (2008) First report of qnrB-producing Enterobacter cloacae and qnrA-producing Acinetobacter baumannii recovered from Algerian hospitals. Diagn. Microbiol. Infect. Dis. 60(3):287-290.

Verhamme, D.T., Prosser, J.I. and Nicol, G.W. (2011) Ammonia concentration determines differential growth of ammonia-oxidising archaea and bacteria in soil microcosms. ISME J. 5(6):1067-1071.

Wang, J., Ma, T., Zhao, L., Lv, J., Li, G., Liang, F. and Liu, R. (2008) PCR-DGGE method for analyzing the bacterial community in a high temperature petroleum reservoir. World J. Microbiol. Biotechnol. 24:1981-1987.

Wellington, E.M., Boxall, A.B., Cross, P., Feil, E.J., Gaze, W.H., Hawkey, P.M., Johnson-Rollings, A.S., Jones, D.L., Lee, N.M., Otten, W., Thomas, C.M. and Williams, A.P. (2013) The role of the natural environment in the emergence of antibiotic resistance in Gram-negative bacteria. Lancet Infect. Dis. 13(2):155-165.

Werner, G., Coque, T.M., Hammerum, A.M., Hope, R., Hryniewicz, W., Johnson, A., Klare, I., Kristinsson, K.G., Leclercq, R., Lester, C.H., Lillie, M., Novais, C., Olsson-Liljequist, B., Peixe, L.V., Sadowy, E., Simonsen, G.S., Top, J., Vuopio-Varkila, J., Willems, R.J., Witte, W. and Woodford, N. (2008) Emergence and spread of vancomycin resistance among enterococci in Europe. Euro Surveill. 13(47) pii: 19046.

Wilhelm, J. and Pingoud, A. (2003) Real-time polymerase chain reaction. Chembiochem. 4(11):1120-1128.

Wright, M.S., Baker-Austin, C., Lindell, A.H., Stepanauskas, R., Stokes, H.W. and McArthur, J.V. (2008) Influence of industrial contamination on mobile genetic elements: class 1 integron abundance and gene cassette structure in aquatic bacterial communities. ISME J. 2(4):417-428.

Wright, G.D. (2010a) Q\&A: Antibiotic resistance: where does it come from and what can we do about it? BMC Biol. 8:123.

Wright, G.D. (2010b) Antibiotic resistance in the environment: a link to the clinic? Curr. Opin. Microbiol. 13(5):589-594.

Wright, M.S., Baker-Austin, C., Lindell, A.H., Stepanauskas, R., Stokes, H.W. and McArthur, J.V. (2008) Influence of industrial contamination on mobile genetic elements: class 1 integron abundance and gene cassette structure in aquatic bacterial communities. ISME J. 2(4):417-428.

Wu, S., Dalgaard, A., Hammerum, A.M., Porsbo, L.J. and Jensen, L.B. (2010) Prevalence and characterization of plasmids carrying sulfonamide resistance genes among Escherichia coli from pigs, pig carcasses and human. Acta Vet. Scand. 52:47.

Xu, X., Wu, S., Ye, X., Liu, Y., Shi, W., Zhang, Y. and Wang, M. (2007) Prevalence and expression of the plasmid-mediated quinolone resistance determinant qniA1. Antimicrob. Agents Chemother. 51(11):4105-4110.

Zhang, X.X. and Zhang, T. (2011) Occurrence, abundance, and diversity of tetracycline resistance genes in 15 sewage treatment plants across China and other global locations. Environ. Sci. Technol. 45(7):2598-2604. 


\section{Papers}

The articles associated with this thesis have been removed for copyright reasons. For more details about these see:

http://urn.kb.se/resolve?urn=urn:nbn:se:liu:diva-105872 